\title{
Does Environment has any role in recovery from COVID-19 pandemic? A case study from India.
}

Amitesh Gupta ( $\nabla$ amitesh13gupta14@gmail.com )

RBased Services Pvt. Ltd.

Labani Saha

Savitribai Phule Pune University

\section{Research Article}

Keywords: COVID-19, recovery, air quality, meteorology, India

Posted Date: June 29th, 2021

DOI: https://doi.org/10.21203/rs.3.rs-665840/v1

License: (c) (1) This work is licensed under a Creative Commons Attribution 4.0 International License. Read Full License 


\section{Abstract}

The present study has investigated the role of meteorology and air quality for recovering from the COVID19 pandemic in India. Using Pearson's correlation method, we look into if there is any significant association occurs between the district level recovery case counts and different remote sensing based environmental variables. Among weather parameters, only precipitation and air temperature found to be significantly correlated with recovery situation. However, all the pollutants' concentration was negatively correlated with count of recovery cases. It depicts that air quality might has greater importance in recovery from this disease. During late monsoon onwards, recovery rate was getting more than the infections which indicate that lesser temperature and good rainfall could help the air to be freshen. Through air pollution was greater during winter and post monsoon than the summer season in India the higher recovery rate was counted during post-monsoon and winter which suggest that patients may require lesser temperate ambient for better recovery. Spatial patterns also suggest that north-eastern hilly region followed by districts located in the northern mountain had better recovery where the pollutants' concentration was also quite lower during the study period. Therefore, improving air quality with proper preventive precaution could help to combat the pandemic situation in India.

\section{Introduction}

In the year 2020, world has experienced one of the deadliest pandemics in human history ever with a death count of 2501229 and confirm cases count of 112649371 globally as of 03:39 pm CET, February 26, 2021 (https://covid19.who.int/). It started since December 2019 when a pneumonia infection broke out in Wuhan, Hubei province, China, which was then named as Novel Coronavirus Pneumonia (NCP), started spreading all over the country ((Liu et al., 2020). Gradually it has spread all over the world ((Bertuzzo et al., 2020; Gorbalenya et al., 2020). WHO started with epidemiological and operational updates about COVID-19 on their website since January 21 of 2020 and by March 11, 2020 the director general of the organization briefed the media by declaring COVID-19 as pandemic. In the situation report10 that was published on January 30,2020 , WHO had already announced the first confirmed case of India and also stated it to have a travel history to Wuhan.

A few researchers have already exhorted about significant association of environmental parameters to COVID-19 transmission (Azuma et al., 2020; Bherwani et al., 2020; Eslami and Jalili, 2020; Gupta and Pradhan, 2020a; Kifer et al., 2021; Rume and Islam, 2020; Saadat et al., 2020; Shakil et al., 2020). There are also a few global as well as regional studies that had been carried out in the context of China, USA, England, Germany, Spain, Italy, Indonesia, Iran, Pakistan, Bangladesh, India, and found significant correlation between weather parameters and the COVID-19 cases (Ahmadi et al., 2020; Chen et al., 2021; Fadli et al., 2020; Ficetola and Rubolini, 2021; Gupta et al., 2020a; Gupta and Pradhan, 2020b; Islam et al., 2020; Liu et al., 2020b; Ma et al., 2020; Mehmood et al., 2021; Nottmeyer and Sera, 2021; Oliveiros et al., 2020; Qi et al., 2020; Tosepu et al., 2020). Studies carried out by Bochenek et al., 2021; Borah et al., 2020; Briz-Redón and Serrano-Aroca, 2020; Emediegwu, 2021; Guo et al., 2021; Gupta et al., 2020b; Mecenas et al., 2020; Runkle et al., 2020; Şahin, 2020; Sil and Kumar, 2020 suggested that warm and humid condition 
seem to foreshorten the proliferation of COVID-19. On the other hand, Al-Rousan and Al-Najjar, 2020; Awasthi et al., 2020; Bashir et al., 2020a; Fawad et al., 2021; Gupta and Pradhan, 2020a; Kumar and Kumar, 2020; Pani et al., 2020; Sangkham et al., 2021; Selcuk et al., 2021; Sharma et al., 2021 reported that hotter days might be more susceptible for COVID-19 dissemination while the role of humidity was still incongruous (Aidoo et al., 2021; Auler et al., 2020; Gupta et al., 2020c; Kumar, 2020; Yuan et al., 2021). Menebo, 2020 found negative association between precipitation and COVID-19 cases, contrary to Byass, 2020; while Gunthe et al., 2020 found no significance of precipitation and cloudiness for this outbreak.

On the other hand, the carbonaceous pollutants i.e. $\mathrm{CO}$ and $\mathrm{BC}$ and $\mathrm{OC}$, which also includes the primary and secondary organic carbon, are mainly produced during different anthropogenic activities of biomass burning and fossil fuel combustion, with relatively little contribution from various natural sources ( $\mathrm{Li}$ et al., 2016; Prabhu et al., 2020; Schmidt, 2011; Wang et al., 2019; Winiger et al., 2016; Zhang and Wang, 2011). AOD, an indicant of Particulate Matter pollution (Chudnovsky et al., 2014; Engel-Cox et al., 2004; Gupta et al., 2021; Karimian et al., 2016), has not been often related to such malady study. Since the significant relation between prevailing weather conditions and regional pollution level is well demonstrated by various studies, it becomes very crucial to behold the role of meteorology and air quality togetherly to conceive the seasonality of such savage seizure of coronavirus.

Human respiratory viruses transmit through human contact, mainly through coughs and breathes of the infected person (Leung et al., 2020) as the virus generated through sneeze and coughs are contained by the aerosols (Srivastava, 2021; Barcelo, 2020) for which WHO has given several guidelines regarding travelling, public gathering and personal care with an aim to minimize the physical contact. In a tropical country like Bangladesh no direct relation between the number of COVID-19 cases and meteorological parameters were detected but there was significant positive correlation of them with the contact transmission (Islam et al., 2021). In a case of Iran, it was estimated that population over 1.7 million can trigger the transmission (Jahangiri et al., 2020). However, there are several environmental factors those influence the transmission of respiratory viruses such as humidity, temperature, airflow etc. (Pica and Bouvier, 2012). Air quality also has serious impact on it inducing various respiratory problems since, exposure to some air pollutants can worsen the infection (Domingo and Rovira, 2020; Li et al., 2020). It was found that higher concentration of ambient carbon mono-oxide can play a key role in greater transmission (Lin et al., 2020). It was also found that PM2.5 can significantly increase both confirm (Sharma et al., 2021) and death counts (Jain et al., 2021). Even, different countries, with their different climatic scenario have shown different kinds of association with the spread of COVID-19 (Doğan et al., 2020; Pani et al., 2020; Singh and Agarwal, 2020). Sometimes humidity is found to be the best predictor of COVID-19 transmission (Runkle et al., 2020) with absolute humidity having a positive correlation with the number of cases (Luo et al., 2020). Low temperature countries were advised to adopt strict measurements to combat the situation (Wang et al., 2020). A study in Kuala Lumpur, Malaysia, with the help of Spearman's correlation test has shown a positive correlation of COVID-19 transmission with relative humidity and air pollutants such as particulate matters and gaseous contents but displayed a negative correlation with the ambient temperature (Suhaimi et al., 2020). In Turkey with the help of spearman's correlation test it was found that higher the average temperature of the first day of the 14 
days incubation period, lower the number of cases (Şahin, 2020). Another study that had taken national and region-specific data from Germany, Italy, Spain and United Kingdom and put them into a non-linear model has concluded that cold and dry environments are likely to facilitate the COVID-19 transmission (Fu et al., 2021). With low temperature, studies have explored mild diurnal temperature range and low humidity to play significant role in rise in transmission (Liu et al., 2020). Studies have even shown that in the context of China increase in the temperature will significantly decrease the doubling rate of cases (Oliveiros; et al., 2020). These results started piling up hope amongst people from all over the world that the situation will get back to normal in the upcoming summer season (Karapiperis et al., 2020; Shi et al., 2020; Kaplin et al., 2021). However, several studies, have shown completely opposite results (Kumar, 2020; Sahafizadeh and Sartoli, 2020; Ceylan, 2021; Hridoy et al., 2021; Jain et al., 2021). A study in the equatorial country Brazil, with the help of principal component analysis and linear regression analysis, has shown that higher mean temperature and average relative humidity favor the COVID-19 transmission (Auler et al., 2020). A very recent study in China added rainfall in the same category i.e., positively correlated with case counts (Chen et al., 2021). In India it has been suggested that hot and dry regions of lower altitude shall be most affected by the COVID-19 transmission (Gupta et al., 2020a). A study in Turkey has found positive correlation of number of cases with almost all the parameters (temperature, wind speed, population density etc.) except humidity (Saraç and Koyuncu, 2020). Amidst this turmoil situation, the major question in front of the world now is when shall the situation get back to normal and how?

A Delhi based study, during the initial period of pandemic, estimated that it will take almost 10 months for complete recovery from COVID-19, having said that with an increase in $1{ }^{\circ} \mathrm{C}$ in the temperature about 30 cases will recover every day (Awasthi et al., 2021). A study in Jakarta, Indonesia shows that exposure to sunlight is showing a significantly better recovery among patients (Asyary and Veruswati, 2020). Bhattacharjee et al., 2021 predicts that in India the number of patients will start declining when the case load rate (Confirmed cases - Recovered cases - Deaths) goes lesser than the recovery rate. As of now, there is no significant study available to explain how under existing climatic condition of India the recovery of COVID-19 patients shall be influenced. Hence, this paper aims at taking a close look into the relationship between the meteorological factors and recovery rate in the country.

Scanty studies have been carried out on the importance of freshen air for the melioration of human health and to elude any convalescence (Cragg et al., 2016; Kampa and Castanas, 2008; Manisalidis et al., 2020; White et al., 2019). Likewise, scarcely any study has been fanatical about the significance of weather parameters on COVID-19 recovery, even though $93.88 \%$ of the sufferers have been healed in India, slightly lesser than the global recovery rate (97.42\%) till March 31, 2021. Since a handful of studies had reckoned that the inferior air quality had efficaciously swayed to aggravate the COVID-19 emanation, hence it becomes also requisite to investigate whether the convivial air quality has been benevolent to convalesce the COVID-19 patients in India. Till date, seldom study might have inspected the yearlong period of pandemic situation while minimal have rendered any estimation on this. Therefore, the present study has been firmed to analyse the association of COVID-19 incidences (i.e. transmission) and recovery 
cases with weather and air quality parameters across the country, as well as proffered a comparative assessment for estimating confirm and recovery cases availing the non-linear complex relationship.

\section{Data And Methodology}

Counts of Confirmed and Recovered cases for all the available districts in India have been acquired from https://www.covid19india.org/. Spatial data for total six different meteorological parameters - 2-m Air Temperature (AT), Bias-corrected Total Precipitation (PRC), Specific Humidity (Hm), Cloud Cover (CLD), Incoming Short-wave Radiation (ISWR), Wind Speed (WS), and six different air quality parameters Aerosol Optical Depth (AOD), Tropospheric Column Nitrogen di-Oxide $\left(\mathrm{NO}_{2}\right)$, Total Column Ozone $\left(\mathrm{O}_{3}\right)$, Surface concentration of Carbon Monoxide (CO), Sulphur di-Oxide $\left(\mathrm{SO}_{2}\right)$ and Black Carbon (BC) have been incorporated in the present study. Remote Sensing based datasets are highly useful for various environmental studies (Bhatt et al., 2021; Das et al., 2017; Das and Gupta, 2021; Gupta et al., 2020b; Gupta et al., 2019; Moniruzzam et al., 2018; Nanda et al., 2018; Rousta et al., 2020), hence we have used such dataset from different sources. Monthly mean of these twelve environmental variables were further processed in ArcGIS software, adjoined and related with the monthly cumulative counts of confirmed and recovery cases for each months for each of those selected districts.

Infections and recoveries during 1st COVID-19 waves in India

The district wise spatial distribution of COVID-19 confirmed cases and recoveries during the 1st COVID-19 wave (up to March, 2021) are shown in Figure 1. It shows that most of the districts have registered counts of recoveries within the range of 2500-5000 following the range of 10000-25000. Comprehensively, 20 states had recoveries of that same count; among them only Maharashtra and Kerala had registered more than 10 lakh. All states had more than 90\% recovery cases except Maharashtra, Chandigarh and Punjab; whereas Mizoram and Arunachal Pradesh incidentally had more than $99 \%$ of recovery. Approximately $15 \%$ of the total districts in India mostly from the North-Eastern hilly areas and very few from the interior of Peninsular Plateau region had reported more than $99 \%$ of recovery. During summer, the average recovery rate of all provinces was unanticipatedly lower (56.96\%), whereas a progressive improvement was perceptible during monsoon (78.87\%), post-monsoon (119.62\%) and winter (130.02\%). Noteworthy, recovery rate of higher than $100 \%$ in any province during a month or season indicates that a greater number of people had been recovered than being infected in that duration, i.e. recovery counts had surpassed the count of confirmed cases. The daily count of recovery cases was lower than infective cases throughout the summer and since late September the recovery cases were far ahead in count than infections.

Pearson's correlation test

Pearson's correlation technique was applied to explore the degree of association of environmental parameters with infected and recovered cases at $95 \%$ confidence interval using equation 1 . A correlogram is also being prepared to better represent the interrelation of the variables of the input dataset. 


$$
r=\frac{\sum_{i=1}^{n}\left(E n_{i}-\overline{E n}\right)\left(C_{i}-\bar{C}\right)}{\sqrt{\sum_{i=1}^{n}\left(E n_{i}-\overline{E n}\right)^{2} \sum_{i=1}^{n}\left(C_{i}-\bar{C}\right)^{2}}}
$$

Here, $r$ is the correlation coefficient, En represents the environmental variables, $C$ denotes the count of confirm and recovery cases individually.

Statistical Measures

The descriptive statistics (mean, median, mode, standard deviation, standard error, range) of the input variables used for the analysis have been put in Table 2 (descriptive statistics). The entire dataset of 4020 observations was alienated into a $70: 30$ ratio, where $70 \%$ of the data were used to train the models and the rest $30 \%$ data were used for its evaluation. Furthermore, in order to investigate the spatial influence of environmental parameters, monthly average values of all 12 variables were appended with monthly cumulative counts of confirmed and recovery cases noted over 335 major affected districts across the country during the yearlong period.

\section{Results And Discussion}

Through the Pearson's correlation test we found non-significant association between the recovery counts and ISWR (0.163), Hm (0.104), WS (0.063) and CLD (-0.127), while only AT (-0.216) and PRC (0.398) found to be significantly correlated with recovery. Moore and Little, 2007; Al Ashry and Modrykamien, 2014; Kelly et al., 2010 also highlighted the relevance of humidification. Besides, precipitation results scavenging of aerosols (Andronache, 2016; Kim et al., 2014; Pan et al., 2017; Zhang et al., 2004),. The negative correlation between the AT and recovery cases suggests that patients might have recovered comparatively better in lesser temperature conditions. Recently, Y. Liu et al., 2020d; Shahri et al., 2021; Yang et al., 2020b have found that thrombocytopenia could increase the mortality risk among COVID-19 patients. It was also noticed that the daily count of recovery cases exceeded the confirmed cases after mid-September, 2020 and this parallel pattern continued up to the end of January, 2021 when the AT was continuously decreasing. Simultaneously, we have also noticed that the districts located at higher altitudes in north and north-east India, naturally experience relatively lesser AT, had registered more than $97 \%$ of recovery which was considerably better than the other districts located in the plain or low-lying region. Since AT started to rise February onwards the daily infections also noted to rise and outpaced the daily count of recoveries. Hence, the surrounding AT can be adjudged as a vital factor both in case of transmission and recuperation of COVID-19 in India. The non-significant correlation of recoveries with CLD, WS, Hm still remains subject of further investigations in this context.

Precipitation is a key factor in the reduction of air pollution (Roldán-Henao et al., 2020; Zheng et al., 2019). Greater CLD also slows down the rising trend in AT by radiative cooling effect (Gettelman and Sherwood, 2016). According to Akimoto et al., 2015; Desideri et al., 2007; Steffens, 2020; Wang and Su, 2020 , the $\mathrm{O}_{3}$ decrease during the presence of higher humidity levels, hence the $\mathrm{O}_{3}$ formation also got reduced during the rainy season and depleted by depositing on water droplets. The negative correlation 
between fine PM and precipitation is often registered in umpteen studies (Gupta et al., 2020e; Pandey et al., 2017; Wang and Ogawa, 2015; Wu et al., 2018b). Thus the concentration of fine PM including the dust which was earlier conjectured for probable expeditious recrudescence of COVID-19 also got reduced during the monsoon precipitation. Earlier Jayamurugan et al., 2013; Shukla et al., 2008 had discussed the deduction of gaseous pollutants due to higher humidity and raindrop formation processes during the rainy season. Therefore it is well understood that the change in weather pattern reduced the air pollution during monsoon season, and during the post-monsoon and winter seasons the pollution levels had regained their peak due to the shortage of precipitation and humidity. We have also noted that recovery counts had significantly negative correlation $(p<0.05)$ with all the pollutants during the study period. $\mathrm{O}_{3}$ had better inverse association (-0.384) followed by AOD (-0.355), $\mathrm{CO}(-0.353), \mathrm{NO}_{2}(-0.328), \mathrm{BC}(-0.264)$, $\mathrm{SO}_{2}(-0.216)$. It depicts that convalescents had a facile recuperation where the concentration of air pollutants were considerably lower. It also explains why finer air quality over the hilly regions in the NorthEast India might have helped to heal better from this disease. Though the overall country had exhibited notable rise in pollution level during post-monsoon and winter, spatial scenarios depict that the pollutant gases namely $\mathrm{CO}, \mathrm{NO}_{2}$ and $\mathrm{SO}_{2}$ were mostly concentrated over Northern IGP and Eastern Indian region only. BC and AOD values (hence PM levels) were also lesser in Western parts of the country. With a significant congruence, the states located in North-East India had registered more than $135 \%$ and $160 \%$ of recovery during Post-Monsoon and Winter; whereas during the same seasons, the states from West and South India heeded around $124 \%$ of average recovery, fairly better than the provinces in IGP (around 98\%). Therefore we can reasonably descry the escalating betterment of health in less adulterated areas while a gradual revival over tainted regions in the country, which eventually indicates that the recuperation followed by rehabilitation from this pandemic could be attainable in a less polluted environment. Hence ameliorating the air quality by strict regulations and proper preventive measures could help not only to deduce the dissemination of COVID-19 but also preferably assist to convalesce from this disease sooner.

\section{Conclusion}

In short, the correlation of the number of recovered cases with the environmental parameters through the Pearson's correlation test reveals that, increasing PRC and RH have slight impact in increasing the recovery. GRN is strongly positively correlated with the number of recovered cases. It means that, humid areas with higher vegetation cover and precipitation are supposedly going to induce high counts of recovery while the dry areas with lesser precipitation are going to experience surge in the number of confirmed cases. Areas of higher temperature are going to experience a rise in number of confirmed cases along with a slow recovery. Association cloud and wind with both the cases in weak or very weak. Among the other parameters, presence of 03 and $A O D$ shows strong correlation with both the cases, negative with recovery cases. All the other parameters like NO2, BC, CO, OC, SO2 and ISWR are showing weak or moderate correlation with the cases, negative for recovery cases. 
In accordance with the outcomes from the studies carried out by Huang et al., 2020b; Sarkodie and Owusu, 2020, we found precipitation to be beneficial for the better recovery. People residing in the area with lesser Temp recovered in greater count while Hm, WS, CLD didn't pose any significance as observed during the study period. During or in a later stage of treatment, several patients are also condemned to various post-syndrome infections mostly related to cardiovascular and respiratory disorders which might be the ramifications of virulent vulnerability to the gaseous pollution. Hence it altogether asserts that the environment needs to be ameliorated immensely by its standards to alleviate such deadly pandemic. The injurious impact of traffic pollution has also been discussed through various global and regional studies (Gauderman et al., 2007; Laumbach and Kipen, 2012; Urman et al., 2014). Considering those cognizance

along with the observations throughout the study, it may be opined that the complete lockdown with strict regulations could substantially decrease the pollution levels, and so the dissemination rate of COVID-19 too. The pre-eminence of weather parameters on air quality is indubitable and evinced globally (Bhaskar and Mehta, 2010; Fisher, 2002; Yansui Liu et al., 2020e; Panofsky and Prasad, 1967; Qin et al., 2020; Seo et al., 2018; Zhang et al., 2015), hence its significant association with COVID-19 dissemination during a year-long period over India has been certainly revealed through the present study. We also postulate that amelioration from this pandemic could be viable, preferably in a freshened (less polluted) environment with non-scorching weather conditions. The outcomes conjectured that patients might recover better breathing freshened moist air and if surrounding air quality can be eloquently moderated, the current pandemic can be assuaged as well. This disquisition will irrefutably succour the government administrations including the policy makers across the country to instigate proper preparedness and effectuate requisite manoeuvres impeding the parlous ramifications of COVID-19 in forthcoming days.

\section{Declarations}

Authors declare no conflict of interest.

\section{References}

Agius, A.M., Smallman, L.A., Pahor, A.L., 1998. Age, smoking and nasal ciliary beat frequency. Clin Otolaryngol Allied Sci 23, 227-230. https://doi.org/10.1046/j.1365-2273.1998.00141.x

Ahmadi, M., Sharifi, A., Dorosti, S., Jafarzadeh Ghoushchi, S., Ghanbari, N., 2020. Investigation of effective climatology parameters on COVID-19 outbreak in Iran. Science of The Total Environment 729, 138705. https://doi.org/10.1016/j.scitotenv.2020.138705

Aidoo, E.N., Adebanji, A.O., Awashie, G.E., Appiah, S.K., 2021. The effects of weather on the spread of COVID-19: evidence from Ghana. Bull Natl Res Cent 45, 20. https://doi.org/10.1186/s42269-021-00484-3

Akimoto, H., Mori, Y., Sasaki, K., Nakanishi, H., Ohizumi, T., Itano, Y., 2015. Analysis of monitoring data of ground-level ozone in Japan for long-term trend during 1990-2010: Causes of temporal and spatial variation. Atmospheric Environment 102, 302-310. https://doi.org/10.1016/j.atmosenv.2014.12.001 
Al Ashry, H.S., Modrykamien, A.M., 2014. Humidification during Mechanical Ventilation in the Adult Patient. BioMed Research International 2014, e715434. https://doi.org/10.1155/2014/715434

Alag, S., 2020. Analysis of COVID-19 clinical trials: A data-driven, ontology-based, and natural language processing approach. PLOS ONE 15, e0239694. https://doi.org/10.1371/journal.pone.0239694

Ali, N., Islam, F., 2020. The Effects of Air Pollution on COVID-19 Infection and Mortality-A Review on Recent Evidence. Front Public Health 8. https://doi.org/10.3389/fpubh.2020.580057

Al-Rousan, N., Al-Najjar, H., 2020. The correlation between the spread of COVID-19 infections and weather variables in 30 Chinese provinces and the impact of Chinese government mitigation plans. Eur Rev Med Pharmacol Sci 24, 4565-4571. https://doi.org/10.26355/eurrev_202004_21042

Analitis, A., de' Donato, F., Scortichini, M., Lanki, T., Basagana, X., Ballester, F., Astrom, C., Paldy, A., Pascal, M., Gasparrini, A., Michelozzi, P., Katsouyanni, K., 2018. Synergistic Effects of Ambient Temperature and Air Pollution on Health in Europe: Results from the PHASE Project. Int J Environ Res Public Health 15. https://doi.org/10.3390/ijerph15091856

Andersson, E.M., Ögren, M., Molnár, P., Segersson, D., Rosengren, A., Stockfelt, L., 2020. Road traffic noise, air pollution and cardiovascular events in a Swedish cohort. Environmental Research 185, 109446. https://doi.org/10.1016/j.envres.2020.109446

Andronache, C., 2016. Dependence of Daily Aerosol Wet Deposition on Precipitation at Appalachian Mountains Site in the United States. Aerosol Air Qual. Res. 16, 665-673.

https://doi.org/10.4209/aaqr.2015.05.0322

Anenberg Susan C., Horowitz Larry W., Tong Daniel Q., West J. Jason, 2010. An Estimate of the Global Burden of Anthropogenic Ozone and Fine Particulate Matter on Premature Human Mortality Using Atmospheric Modeling. Environmental Health Perspectives 118, 1189-1195.

https://doi.org/10.1289/ehp.0901220

Aslam, B., Khalil, U., Azam, U., Maqsoom, A., 2020. A correlation study between weather and atmosphere with COVID-19 pandemic in Islamabad, Pakistan. Spat. Inf. Res. https://doi.org/10.1007/s41324-02000366-2

Asraf, H.M., Nooritawati, M.T., Rizam, M.S.B.S., 2012. A Comparative Study in Kernel-Based Support Vector Machine of Oil Palm Leaves Nutrient Disease. Procedia Engineering, International Symposium on Robotics and Intelligent Sensors 2012 (IRIS 2012) 41, 1353-1359.

https://doi.org/10.1016/j.proeng.2012.07.321

Auler, A.C., Cássaro, F.A.M., da Silva, V.O., Pires, L.F., 2020. Evidence that high temperatures and intermediate relative humidity might favor the spread of COVID-19 in tropical climate: A case study for the 
most affected Brazilian cities. Science of The Total Environment 729, 139090. https://doi.org/10.1016/j.scitotenv.2020.139090

Awasthi, A., Sharma, A., Kaur, P., Gugamsetty, B., Kumar, A., 2020. Statistical interpretation of environmental influencing parameters on COVID-19 during the lockdown in Delhi, India. Environ Dev Sustain. https://doi.org/10.1007/s10668-020-01000-9

Azuma, K., Yanagi, U., Kagi, N., Kim, H., Ogata, M., Hayashi, M., 2020. Environmental factors involved in SARS-CoV-2 transmission: effect and role of indoor environmental quality in the strategy for COVID-19 infection control. Environmental Health and Preventive Medicine 25, 66. https://doi.org/10.1186/s12199020-00904-2

Babu, S.R., Rao, N.N., Kumar, S.V., Paul, S., Pani, S.K., 2020. Plausible Role of Environmental Factors on COVID-19 Transmission in the Megacity Delhi, India. Aerosol Air Qual. Res. 20, 2075-2084.

https://doi.org/10.4209/aaqr.2020.06.0314

Badman, D.G., Jaffé, E.R., 1996. Blood and air pollution: State of knowledge and research needs. Otolaryngology - Head and Neck Surgery 114, 205-208. https://doi.org/10.1016/S0194-5998(96)70166-3

Balakrishnan, K., Dey, S., Gupta, T., Dhaliwal, R.S., Brauer, M., Cohen, A.J., Stanaway, J.D., Beig, G., Joshi, T.K., Aggarwal, A.N., Sabde, Y., Sadhu, H., Frostad, J., Causey, K., Godwin, W., Shukla, D.K., Kumar, G.A., Varghese, C.M., Muraleedharan, P., Agrawal, A., Anjana, R.M., Bhansali, A., Bhardwaj, D., Burkart, K., Cercy, K., Chakma, J.K., Chowdhury, S., Christopher, D.J., Dutta, E., Furtado, M., Ghosh, S., Ghoshal, A.G., Glenn, S.D., Guleria, R., Gupta, R., Jeemon, P., Kant, R., Kant, S., Kaur, T., Koul, P.A., Krish, V., Krishna, B., Larson, S.L., Madhipatla, K., Mahesh, P.A., Mohan, V., Mukhopadhyay, S., Mutreja, P., Naik, N., Nair, S., Nguyen, G., Odell, C.M., Pandian, J.D., Prabhakaran, D., Prabhakaran, P., Roy, A., Salvi, S., Sambandam, S., Saraf, D., Sharma, M., Shrivastava, A., Singh, V., Tandon, N., Thomas, N.J., Torre, A., Xavier, D., Yadav, G., Singh, S., Shekhar, C., Vos, T., Dandona, R., Reddy, K.S., Lim, S.S., Murray, C.J.L., Venkatesh, S., Dandona, L., 2019. The impact of air pollution on deaths, disease burden, and life expectancy across the states of India: the Global Burden of Disease Study 2017. The Lancet Planetary Health 3, e26-e39.

https://doi.org/10.1016/S2542-5196(18)30261-4

Barreca, A.I., 2012. Climate change, humidity, and mortality in the United States. Journal of Environmental Economics and Management 63, 19-34. https://doi.org/10.1016/j.jeem.2011.07.004

Bashir, M.F., Ma, B., Bilal, Komal, B., Bashir, M.A., Tan, D., Bashir, M., 2020a. Correlation between climate indicators and COVID-19 pandemic in New York, USA. Science of The Total Environment 728, 138835. https://doi.org/10.1016/j.scitotenv.2020.138835

Bashir, M.F., Ma, B.J., Bilal, null, Komal, B., Bashir, M.A., Farooq, T.H., Iqbal, N., Bashir, M., 2020 b. Correlation between environmental pollution indicators and COVID-19 pandemic: A brief study in Californian context. Environ Res 187, 109652. https://doi.org/10.1016/j.envres.2020.109652 
Ben-Hur, A., Ong, C.S., Sonnenburg, S., Schölkopf, B., Rätsch, G., 2008. Support Vector Machines and Kernels for Computational Biology. PLOS Computational Biology 4.

https://doi.org/10.1371/journal.pcbi.1000173

Benjamin, S.F., 1975. Study of Topographical Effects on Dispersion of Pollution, in: Frenkiel, F.N., Munn, R.E. (Eds.), Advances in Geophysics, International Union of Theoretical and Applied Mechanics and International Union of Geodesy and Geophysics. Elsevier, p. 380. https://doi.org/10.1016/S00652687(08)60602-0

Bentayeb, M., Wagner, V., Stempfelet, M., Zins, M., Goldberg, M., Pascal, M., Larrieu, S., Beaudeau, P., Cassadou, S., Eilstein, D., Filleul, L., Le Tertre, A., Medina, S., Pascal, L., Prouvost, H., Quénel, P., Zeghnoun, A., Lefranc, A., 2015. Association between long-term exposure to air pollution and mortality in France: A 25-year follow-up study. Environment International 85, 5-14.

https://doi.org/10.1016/j.envint.2015.08.006

Bertuzzo, E., Mari, L., Pasetto, D., Miccoli, S., Casagrandi, R., Gatto, M., Rinaldo, A., 2020. The geography of COVID-19 spread in Italy and implications for the relaxation of confinement measures. Nat Commun 11, 4264. https://doi.org/10.1038/s41467-020-18050-2

Bhaskar, B.V., Mehta, V.M., 2010. Atmospheric Particulate Pollutants and their Relationship with Meteorology in Ahmedabad. Aerosol Air Qual. Res. 10, 301-315.

https://doi.org/10.4209/aaqr.2009.10.0069

Bhatt, C.M., Gupta, A., Roy, A., Dalal, P., Chauhan, P., 2021. Geospatial analysis of September, 2019 floods in the lower gangetic plains of Bihar using multi-temporal satellites and river gauge data. Geomatics, Natural Hazards and Risk 12, 84-102. https://doi.org/10.1080/19475705.2020.1861113

Bherwani, H., Gupta, A., Anjum, S., Anshul, A., Kumar, R., 2020. Exploring dependence of COVID-19 on environmental factors and spread prediction in India. npj Climate and Atmospheric Science 3, 1-13. https://doi.org/10.1038/s41612-020-00142-x

Bochenek, B., Jankowski, M., Gruszczynska, M., Nykiel, G., Gruszczynski, M., Jaczewski, A., Ziemianski, M., Pyrc, R., Figurski, M., Pinkas, J., 2021. Impact of Meteorological Conditions on the Dynamics of the COVID-19 Pandemic in Poland. Int J Environ Res Public Health 18.

https://doi.org/10.3390/ijerph18083951

Borah, M.J., Hazarika, B., Panda, S.K., Nieto, J.J., 2020. Examining the correlation between the weather conditions and COVID-19 pandemic in India: A mathematical evidence. Results in Physics 19, 103587. https://doi.org/10.1016/j.rinp.2020.103587

Bourdrel, T., Annesi-Maesano, I., Alahmad, B., Maesano, C.N., Bind, M.-A., 2021. The impact of outdoor air pollution on COVID-19: a review of evidence from in vitro, animal, and human studies. European Respiratory Review 30. https://doi.org/10.1183/16000617.0242-2020 
Bourdrel, T., Bind, M.-A., Béjot, Y., Morel, O., Argacha, J.-F., 2017. Cardiovascular effects of air pollution. Arch Cardiovasc Dis 110, 634-642. https://doi.org/10.1016/j.acvd.2017.05.003

Briz-Redón, Á., Serrano-Aroca, Á., 2020. A spatio-temporal analysis for exploring the effect of temperature on COVID-19 early evolution in Spain. Science of The Total Environment 728, 138811. https://doi.org/10.1016/j.scitotenv.2020.138811

Brunekreef, B., Holgate, S.T., 2002. Air pollution and health. The Lancet 360, 1233-1242. https://doi.org/10.1016/S0140-6736(02)11274-8

Byass, P., 2020. Eco-epidemiological assessment of the COVID-19 epidemic in China, January-February 2020. Global Health Action 13, 1760490. https://doi.org/10.1080/16549716.2020.1760490

Chauhan, A.J., Johnston, S.L., 2003. Air pollution and infection in respiratory illness. British Medical Bulletin 68, 95-112. https://doi.org/10.1093/bmb/ldg022

Chen, J.-C., Wang, X., Wellenius, G.A., Serre, M.L., Driscoll, I., Casanova, R., McArdle, J.J., Manson, J.E., Chui, H.C., Espeland, M.A., 2015. Ambient air pollution and neurotoxicity on brain structure: Evidence from women's health initiative memory study. Annals of Neurology 78, 466-476.

https://doi.org/10.1002/ana.24460

Chen, S., Prettner, K., Kuhn, M., Geldsetzer, P., Wang, C., Bärnighausen, T., Bloom, D.E., 2021. Climate and the spread of COVID-19. Sci Rep 11, 9042. https://doi.org/10.1038/s41598-021-87692-z

Chen, T.-M., Gokhale, J., Shofer, S., Kuschner, W.G., 2007. Outdoor air pollution: nitrogen dioxide, sulfur dioxide, and carbon monoxide health effects. Am J Med Sci 333, 249-256.

https://doi.org/10.1097/MAJ.0b013e31803b900f

Chudnovsky, A.A., Koutrakis, P., Kloog, I., Melly, S., Nordio, F., Lyapustin, A., Wang, Y., Schwartz, J., 2014. Fine particulate matter predictions using high resolution Aerosol Optical Depth (AOD) retrievals. Atmospheric Environment 89, 189-198. https://doi.org/10.1016/j.atmosenv.2014.02.019

Ciencewicki, J., Jaspers, I., 2007. Air Pollution and Respiratory Viral Infection. Inhalation Toxicology 19, 1135-1146. https://doi.org/10.1080/08958370701665434

Coccia, M., 2021. How do low wind speeds and high levels of air pollution support the spread of COVID19? Atmospheric Pollution Research 12, 437-445. https://doi.org/10.1016/j.apr.2020.10.002

Coker, E.S., Cavalli, L., Fabrizi, E., Guastella, G., Lippo, E., Parisi, M.L., Pontarollo, N., Rizzati, M., Varacca, A., Vergalli, S., 2020. The Effects of Air Pollution on COVID-19 Related Mortality in Northern Italy. Environ Resource Econ 76, 611-634. https://doi.org/10.1007/s10640-020-00486-1

Comunian, S., Dongo, D., Milani, C., Palestini, P., 2020. Air Pollution and COVID-19: The Role of Particulate Matter in the Spread and Increase of COVID-19's Morbidity and Mortality. Int J Environ Res Public Health 
Cragg, L., Williams, S., Chavannes, N.H., 2016. FRESH AIR: an implementation research project funded through Horizon 2020 exploring the prevention, diagnosis and treatment of chronic respiratory diseases in low-resource settings. npj Primary Care Respiratory Medicine 26, 1-5.

https://doi.org/10.1038/npjpcrm.2016.35

Dalziel, B.D., Kissler, S., Gog, J.R., Viboud, C., Bjørnstad, O.N., Metcalf, C.J.E., Grenfell, B.T., 2018.

Urbanization and humidity shape the intensity of influenza epidemics in U.S. cities. Science 362, 75-79. https://doi.org/10.1126/science.aat6030

D’Amato, M., Molino, A., Calabrese, G., Cecchi, L., Annesi-Maesano, I., D’Amato, G., 2018. The impact of cold on the respiratory tract and its consequences to respiratory health. Clinical and Translational Allergy 8, 20. https://doi.org/10.1186/s13601-018-0208-9

Das, S., Gupta, A., 2021. Multi-criteria decision based geospatial mapping of flood susceptibility and temporal hydro-geomorphic changes in the Subarnarekha basin, India. Geoscience Frontiers 12, 101206. https://doi.org/10.1016/j.gsf.2021.101206

Das, S., Gupta, A., Ghosh, S., 2017. Exploring groundwater potential zones using MIF technique in semiarid region: a case study of Hingoli district, Maharashtra. Spat. Inf. Res. 25, 749-756. https://doi.org/10.1007/s41324-017-0144-0

Davidson, C.I., Phalen, R.F., Solomon, P.A., 2005. Airborne Particulate Matter and Human Health: A Review. Aerosol Science and Technology 39, 737-749. https://doi.org/10.1080/02786820500191348

Deng, X., Rui, W., Zhang, F., Ding, W., 2013. PM2.5 induces Nrf2-mediated defense mechanisms against oxidative stress by activating PIK3/AKT signaling pathway in human lung alveolar epithelial A549 cells. Cell Biol Toxicol 29, 143-157. https://doi.org/10.1007/s10565-013-9242-5

Desideri, D., Roselli, C., Meli, M.A., Feduzi, L., 2007. Comparison between the diurnal trends of ozone and radon gas concentrations measured at ground in the semi-rural site of Central Italy. J Radioanal Nucl Chem 273, 345-351. https://doi.org/10.1007/s10967-007-6871-2

Dowell, S.F., 2001. Seasonal variation in host susceptibility and cycles of certain infectious diseases. Emerg Infect Dis 7, 369-374. https://doi.org/10.3201/eid0703.010301

Emediegwu, L.E., 2021. Health impacts of daily weather fluctuations: Empirical evidence from COVID-19 in U.S. counties. Journal of Environmental Management 291, 112662.

https://doi.org/10.1016/j.jenvman.2021.112662

Engel-Cox, J.A., Hoff, R.M., Haymet, A.D.J., 2004. Recommendations on the Use of Satellite RemoteSensing Data for Urban Air Quality. Journal of the Air \& Waste Management Association 54, 1360-1371. https://doi.org/10.1080/10473289.2004.10471005 
Eslami, H., Jalili, M., 2020. The role of environmental factors to transmission of SARS-CoV-2 (COVID-19). AMB Express 10. https://doi.org/10.1186/s13568-020-01028-0

Eum, Y., Song, I., Kim, H.-C., Leem, J.-H., Kim, S.-Y., 2015. Computation of geographic variables for air pollution prediction models in South Korea. Environ Health Toxicol 30.

https://doi.org/10.5620/eht.e2015010

Fadli, A., Nugraha, A.W.W., Aliim, M.S., Taryana, A., Kurniawan, Y.I., Purnomo, W.H., 2020. Simple Correlation Between Weather and COVID-19 Pandemic Using Data Mining Algorithms. IOP Conf. Ser.: Mater. Sci. Eng. 982, 012015. https://doi.org/10.1088/1757-899X/982/1/012015

Fares, A., 2013. Factors Influencing the Seasonal Patterns of Infectious Diseases. Int J Prev Med 4, 128132.

Fawad, M., Mubarik, S., Malik, S.S., Ren, J., 2021. Statistical analysis of COVID-19 infection caused by environmental factors: Evidence from Pakistan. Life Sci 269, 119093.

https://doi.org/10.1016/j.Ifs.2021.119093

Feuyit, G., Nzali, S., Lambi, J.N., Laminsi, S., 2019. Air Quality and Human Health Risk Assessment in the Residential Areas at the Proximity of the Nkolfoulou Landfill in Yaoundé Metropolis, Cameroon. Journal of Chemistry 2019, e3021894. https://doi.org/10.1155/2019/3021894

Ficetola, G.F., Rubolini, D., 2021. Containment measures limit environmental effects on COVID-19 early outbreak dynamics. Science of The Total Environment 761, 144432.

https://doi.org/10.1016/j.scitotenv.2020.144432

Fisher, B., 2002. Meteorological factors influencing the occurrence of air pollution episodes involving chimney plumes. Meteorological Applications 9, 199-210. https://doi.org/10.1017/S1350482702002050

Gallerani, M., Reverberi, R., Salmi, R., Smolensky, M.H., Manfredini, R., 2013. Seasonal variation of platelets in a cohort of Italian blood donors: a preliminary report. European Journal of Medical Research 18, 31. https://doi.org/10.1186/2047-783X-18-31

Gauderman, W.J., Vora, H., McConnell, R., Berhane, K., Gilliland, F., Thomas, D., Lurmann, F., Avol, E., Kunzli, N., Jerrett, M., Peters, J., 2007. Effect of exposure to traffic on lung development from 10 to 18 years of age: a cohort study. The Lancet 369, 571-577. https://doi.org/10.1016/S0140-6736(07)60037-3

Gautam, S., Samuel, C., Gautam, A.S., Kumar, S., 2021. Strong link between coronavirus count and bad air: a case study of India. Environ Dev Sustain. https://doi.org/10.1007/s10668-021-01366-4

Ge, X.-Y., Li, J.-L., Yang, X.-L., Chmura, A.A., Zhu, G., Epstein, J.H., Mazet, J.K., Hu, B., Zhang, W., Peng, C., Zhang, Y.-J., Luo, C.-M., Tan, B., Wang, N., Zhu, Y., Crameri, G., Zhang, S.-Y., Wang, L.-F., Daszak, P., Shi, Z.L., 2013. Isolation and characterization of a bat SARS-like coronavirus that uses the ACE2 receptor. Nature 503, 535-538. https://doi.org/10.1038/nature12711 
Gettelman, A., Sherwood, S.C., 2016. Processes Responsible for Cloud Feedback. Curr Clim Change Rep 2, 179-189. https://doi.org/10.1007/s40641-016-0052-8

Ghude, S.D., Chate, D.M., Jena, C., Beig, G., Kumar, R., Barth, M.C., Pfister, G.G., Fadnavis, S., Pithani, P., 2016. Premature mortality in India due to $\mathrm{PM}_{2.5}$ and ozone exposure: Premature Mortality in India. Geophys. Res. Lett. 43, 4650-4658. https://doi.org/10.1002/2016GL068949

Gorbalenya, A.E., Baker, S.C., Baric, R.S., Groot, R.J. de, Drosten, C., Gulyaeva, A.A., Haagmans, B.L., Lauber, C., Leontovich, A.M., Neuman, B.W., Penzar, D., Perlman, S., Poon, L.L.M., Samborskiy, D., Sidorov, I.A., Sola, I., Ziebuhr, J., 2020. Severe acute respiratory syndrome-related coronavirus: The species and its viruses - a statement of the Coronavirus Study Group. bioRxiv 2020.02.07.937862.

https://doi.org/10.1101/2020.02.07.937862

Guan, W., Ni, Z., Hu, Yu, Liang, W., Ou, C., He, J., Liu, L., Shan, H., Lei, C., Hui, D.S.C., Du, B., Li, L., Zeng, G., Yuen, K.-Y., Chen, R., Tang, C., Wang, T., Chen, P., Xiang, J., Li, S., Wang, Jin-lin, Liang, Z., Peng, Y., Wei, L., Liu, Y., Hu, Ya-hua, Peng, P., Wang, Jian-ming, Liu, J., Chen, Z., Li, G., Zheng, Z., Qiu, S., Luo, J., Ye, C., Zhu, S., Zhong, N., 2020. Clinical Characteristics of Coronavirus Disease 2019 in China. N Engl J Med 382, 1708-1720. https://doi.org/10.1056/NEJMoa2002032

Gujral, H., Sinha, A., 2021. Association between exposure to airborne pollutants and COVID-19 in Los Angeles, United States with ensemble-based dynamic emission model. Environmental Research 194, 110704. https://doi.org/10.1016/j.envres.2020.110704

Gunthe, S.S., Swain, B., Patra, S.S., Amte, A., 2020. On the global trends and spread of the COVID-19 outbreak: preliminary assessment of the potential relation between location-specific temperature and UV index. J Public Health (Berl.). https://doi.org/10.1007/s10389-020-01279-y

Guo, C., Bo, Y., Lin, C., Li, H.B., Zeng, Y., Zhang, Y., Hossain, M.S., Chan, J.W.M., Yeung, D.W., Kwok, K.-O., Wong, S.Y.S., Lau, A.K.H., Lao, X.Q., 2021. Meteorological factors and COVID-19 incidence in 190 countries: An observational study. Sci Total Environ 757, 143783.

https://doi.org/10.1016/j.scitotenv.2020.143783

Guo, C., Zhang, Z., Lau, A.K.H., Lin, C.Q., Chuang, Y.C., Chan, J., Jiang, W.K., Tam, T., Yeoh, E.-K., Chan, T.-C., Chang, L.-Y., Lao, X.Q., 2018. Effect of long-term exposure to fine particulate matter on lung function decline and risk of chronic obstructive pulmonary disease in Taiwan: a longitudinal, cohort study. The Lancet Planetary Health 2, e114-e125. https://doi.org/10.1016/S2542-5196(18)30028-7

Gupta, A., Asopa, U., Bhattacharjee, R., 2019. Land Subsidence Monitoring in Jagadhri City Using Sentinel 1 Data and DInSAR Processing. Proceedings 24, 25. https://doi.org/10.3390/IECG2019-06230

Gupta, A., Banerjee, S., Das, S., 2020a. Significance of geographical factors to the COVID-19 outbreak in India. Model. Earth Syst. Environ. 6, 2645-2653. https://doi.org/10.1007/s40808-020-00838-2 
Gupta, A., Bhatt, C.M., Roy, A., Chauhan, P., 2020d. COVID-19 lockdown a window of opportunity to understand the role of human activity on forest fire incidences in the Western Himalaya, India. CURRENT SCIENCE $119,9$.

Gupta, A., Kant, Y., Mitra, D., Chauhan, P., 2021. Spatio-temporal distribution of INSAT-3D AOD derived particulate matter concentration over India. Atmospheric Pollution Research 12, 159-172. https://doi.org/10.1016/j.apr.2020.08.031

Gupta, A., Moniruzzaman, M., Hande, A., Rousta, I., Olafsson, H., Mondal, K.K., 2020e. Estimation of particulate matter (PM2.5, PM10) concentration and its variation over urban sites in Bangladesh. SN Appl. Sci. 2, 1993. https://doi.org/10.1007/s42452-020-03829-1

Gupta, A., Pradhan, B., 2020a. Impact of Daily Weather on COVID-19 outbreak in India. https://doi.org/10.1101/2020.06.15.20131490

Gupta, A., Pradhan, B., 2020b. Assessment of temporal trend of COVID-19 outbreak in India. https://doi.org/10.31219/osf.io/qyre6

Gupta, A., Pradhan, B., Maulud, K.N.A., 2020c. Estimating the Impact of Daily Weather on the Temporal Pattern of COVID-19 Outbreak in India. Earth Syst Environ 4, 523-534. https://doi.org/10.1007/s41748020-00179-1

Gupta, P., Christopher, S.A., 2009. Particulate matter air quality assessment using integrated surface, satellite, and meteorological products: 2. A neural network approach. J. Geophys. Res. 114, D20205. https://doi.org/10.1029/2008JD011497

Gupta, P., Christopher, S.A., Wang, J., Gehrig, R., Lee, Y., Kumar, N., 2006. Satellite remote sensing of particulate matter and air quality assessment over global cities. Atmospheric Environment 40, 58805892. https://doi.org/10.1016/j.atmosenv.2006.03.016

Gupta, S., Raghuwanshi, G.S., Chanda, A., 2020b. Effect of weather on COVID-19 spread in the US: A prediction model for India in 2020. Science of The Total Environment 728, 138860.

https://doi.org/10.1016/j.scitotenv.2020.138860

Hahon, N., Booth, J.A., Green, F., Lewis, T.R., 1985. Influenza virus infection in mice after exposure to coal dust and diesel engine emissions. Environmental Research 37, 44-60. https://doi.org/10.1016/00139351(85)90048-9

Harapan, H., Itoh, N., Yufika, A., Winardi, W., Keam, S., Te, H., Megawati, D., Hayati, Z., Wagner, A.L., Mudatsir, M., 2020. Coronavirus disease 2019 (COVID-19): A literature review. Journal of Infection and Public Health 13, 667-673. https://doi.org/10.1016/j.jiph.2020.03.019

Hatzianastassiou, N., Matsoukas, C., Fotiadi, A., Pavlakis, K.G., Drakakis, E., Hatzidimitriou, D., Vardavas, I., 2005. Global distribution of Earth's surface shortwave radiation budget. Atmos. Chem. Phys. 21. 
Hewson, E.W., Olsson, L.E., 1967. Lake Effects on Air Pollution Dispersion. Journal of the Air Pollution Control Association 17, 757-761. https://doi.org/10.1080/00022470.1967.10469069

Holshue, M.L., DeBolt, C., Lindquist, S., Lofy, K.H., Wiesman, J., Bruce, H., Spitters, C., Ericson, K., Wilkerson, S., Tural, A., Diaz, G., Cohn, A., Fox, L., Patel, A., Gerber, S.I., Kim, L., Tong, S., Lu, X., Lindstrom, S., Pallansch, M.A., Weldon, W.C., Biggs, H.M., Uyeki, T.M., Pillai, S.K., 2020. First Case of 2019 Novel Coronavirus in the United States. New England Journal of Medicine 382, 929-936.

https://doi.org/10.1056/NEJMoa2001191

Hong, H., Pradhan, B., Bui, D.T., Xu, C., Youssef, A.M., Chen, W., 2017. Comparison of four kernel functions used in support vector machines for landslide susceptibility mapping: a case study at Suichuan area (China). Geomatics, Natural Hazards and Risk 8, 544-569.

https://doi.org/10.1080/19475705.2016.1250112

Huang, C., Wang, Y., Li, X., Ren, L., Zhao, J., Hu, Y., Zhang, L., Fan, G., Xu, J., Gu, X., Cheng, Z., Yu, T., Xia, J., Wei, Y., Wu, W., Xie, X., Yin, W., Li, H., Liu, M., Xiao, Y., Gao, H., Guo, L., Xie, J., Wang, G., Jiang, R., Gao, Z., Jin, Q., Wang, J., Cao, B., 2020a. Clinical features of patients infected with 2019 novel coronavirus in Wuhan, China. The Lancet 395, 497-506. https://doi.org/10.1016/S0140-6736(20)30183-5

Huang, H., Liang, X., Huang, J., Yuan, Z., Ouyang, H., Wei, Y., Bai, X., 2020b. Correlations between Meteorological Indicators, Air Quality and the COVID-19 Pandemic in 12 Cities across China. J Environ Health Sci Engineer 18, 1491-1498. https://doi.org/10.1007/s40201-020-00564-y

Huang, Jing, Li, G., Xu, G., Qian, X., Zhao, Y., Pan, X., Huang, Jian, Cen, Z., Liu, Q., He, T., Guo, X., 2018. The burden of ozone pollution on years of life lost from chronic obstructive pulmonary disease in a city of Yangtze River Delta, China. Environmental Pollution 242, 1266-1273.

https://doi.org/10.1016/j.envpol.2018.08.021

Huang, N.-H., Wang, Q., Xu, D.-Q., 2008. Immunological effect of PM2.5 on cytokine production in female Wistar rats. Biomed Environ Sci 21, 63-68. https://doi.org/10.1016/S0895-3988(08)60008-2

Hulin, M., Simoni, M., Viegi, G., Annesi-Maesano, I., 2012. Respiratory health and indoor air pollutants based on quantitative exposure assessments. European Respiratory Journal 40, 1033-1045. https://doi.org/10.1183/09031936.00159011

Iqbal, N., Fareed, Z., Shahzad, F., He, X., Shahzad, U., Lina, M., 2020. The nexus between COVID-19, temperature and exchange rate in Wuhan city: New findings from partial and multiple wavelet coherence. Science of The Total Environment 729, 138916. https://doi.org/10.1016/j.scitotenv.2020.138916

Islam, A.R.Md.T., Hasanuzzaman, Md., Azad, Md.A.K., Salam, R., Toshi, F.Z., Khan, Md.S.I., Alam, G.M.M., Ibrahim, S.M., 2020. Effect of meteorological factors on COVID-19 cases in Bangladesh. Environ Dev Sustain. https://doi.org/10.1007/s10668-020-01016-1 
Jacko, R., Breche, T.L., 2009. Air Pollution and Noise Control, in: Environmental Engineering. John Wiley \& Sons, Ltd, pp. 309-393. https://doi.org/10.1002/9780470432822.ch4

Jacob, D.J., 2000. Heterogeneous chemistry and tropospheric ozone. Atmospheric Environment 34, 2131-2159. https://doi.org/10.1016/S1352-2310(99)00462-8

Jacobson, L. da S.V., Hacon, S. de S., Castro, H.A. de, Ignotti, E., Artaxo, P., Saldiva, P.H.N., Leon, A.C.M.P. de, 2014. Acute Effects of Particulate Matter and Black Carbon from Seasonal Fires on Peak Expiratory Flow of Schoolchildren in the Brazilian Amazon. PLOS ONE 9, e104177.

https://doi.org/10.1371/journal.pone.0104177

Jahangiri, Mehdi, Jahangiri, Milad, Najafgholipour, M., 2020. The sensitivity and specificity analyses of ambient temperature and population size on the transmission rate of the novel coronavirus (COVID-19) in different provinces of Iran. Sci Total Environ 728, 138872.

https://doi.org/10.1016/j.scitotenv.2020.138872

Jain, M., Sharma, G.D., Goyal, M., Kaushal, R., Sethi, M., 2021. Econometric analysis of COVID-19 cases, deaths, and meteorological factors in South Asia. Environ Sci Pollut Res 28, 28518-28534. https://doi.org/10.1007/s11356-021-12613-6

Jamil, T., Alam, I.S., Gojobori, T., Duarte, C., 2020. No Evidence for Temperature-Dependence of the COVID19 Epidemic. medRxiv 2020.03.29.20046706. https://doi.org/10.1101/2020.03.29.20046706

Jana, S., Gupta, A., Nath, A., 2020. Assessment of Global Performance on COVID-19 Research during 1990-2019: An Exploratory Scientometric Analysis 19.

Janssen, N.A.H., Hoek, G., Simic-Lawson, M., Fischer, P., van Bree, L., ten Brink, H., Keuken, M., Atkinson, R.W., Anderson, H.R., Brunekreef, B., Cassee, F.R., 2011. Black Carbon as an Additional Indicator of the Adverse Health Effects of Airborne Particles Compared with PM10 and PM2.5. Environ Health Perspect 119, 1691-1699. https://doi.org/10.1289/ehp.1003369

Jayamurugan, R., Kumaravel, B., Palanivelraja, S., Chockalingam, M.P., 2013. Influence of Temperature, Relative Humidity and Seasonal Variability on Ambient Air Quality in a Coastal Urban Area. International Journal of Atmospheric Sciences 2013, e264046. https://doi.org/10.1155/2013/264046

Jebur, M.N., Pradhan, B., Tehrany, M.S., 2014. Manifestation of LiDAR-Derived Parameters in the Spatial Prediction of Landslides Using Novel Ensemble Evidential Belief Functions and Support Vector Machine Models in GIS. IEEE J. Sel. Top. Appl. Earth Observations Remote Sensing 8, 674-690. https://doi.org/10.1109/JSTARS.2014.2341276

Joshi, M., Pedersen, T., Maclin, R., 2005. A Comparative Study of Support Vector Machines Applied to the Supervised Word Sense Disambiguation Problem in the Medical Domain. Presented at the 2nd Indian International Conference on Artifitial Intelligence (IICAI-05), pp. 3449-3468. 
Jung, R.G., Di Santo, P., Clifford, C., Prosperi-Porta, G., Skanes, S., Hung, A., Parlow, S., Visintini, S., Ramirez, F.D., Simard, T., Hibbert, B., 2021. Methodological quality of COVID-19 clinical research. Nature Communications 12, 943. https://doi.org/10.1038/s41467-021-21220-5

Kampa, M., Castanas, E., 2008. Human health effects of air pollution. Environmental Pollution, Proceedings of the 4th International Workshop on Biomonitoring of Atmospheric Pollution (With Emphasis on Trace Elements) 151, 362-367. https://doi.org/10.1016/j.envpol.2007.06.012

Karimian, H., Li, Q., Li, C., Jin, L., Fan, J., Li, Y., 2016. An Improved Method for Monitoring Fine Particulate Matter Mass Concentrations via Satellite Remote Sensing. Aerosol Air Qual. Res. 16, 1081-1092. https://doi.org/10.4209/aaqr.2015.06.0424

Kelly, M., Gillies, D., Todd, D.A., Lockwood, C., 2010. Heated humidification versus heat and moisture exchangers for ventilated adults and children. Cochrane Database of Systematic Reviews. https://doi.org/10.1002/14651858.CD004711.pub2

Kelsall, J.E., Samet, J.M., Zeger, S.L., Xu, J., 1997. Air Pollution and Mortality in Philadelphia, 1974-1988. American Journal of Epidemiology 146, 750-762. https://doi.org/10.1093/oxfordjournals.aje.a009351

Khaniabadi, Y.O., Hopke, P.K., Goudarzi, G., Daryanoosh, S.M., Jourvand, M., Basiri, H., 2017. Cardiopulmonary mortality and COPD attributed to ambient ozone. Environmental Research 152, 336341. https://doi.org/10.1016/j.envres.2016.10.008

Khorramdelazad, H., Kazemi, M.H., Najafi, A., Keykhaee, M., Zolfaghari Emameh, R., Falak, R., 2021. Immunopathological similarities between COVID-19 and influenza: Investigating the consequences of Coinfection. Microb Pathog 152, 104554. https://doi.org/10.1016/j.micpath.2020.104554

Kifer, D., Bugada, D., Villar-Garcia, J., Gudelj, I., Menni, C., Sudre, C., Vučković, F., Ugrina, I., Lorini, L.F., Posso, M., Bettinelli, S., Ughi, N., Maloberti, A., Epis, O., Giannattasio, C., Rossetti, C., Kalogjera, L., Peršec, J., Ollivere, L., Ollivere, B.J., Yan, H., Cai, T., Aithal, G.P., Steves, C.J., Kantele, A., Kajova, M., Vapalahti, O., Sajantila, A., Wojtowicz, R., Wierzba, W., Krol, Z., Zaczynski, A., Zycinska, K., Postula, M., Lukšić, I., Čivljak, R., Markotić, A., Brachmann, J., Markl, A., Mahnkopf, C., Murray, B., Ourselin, S., Valdes, A.M., Horcajada, J.P., Castells, X., Pascual, J., Allegri, M., Primorac, D., Spector, T.D., Barrios, C., Lauc, G., 2021. Effects of Environmental Factors on Severity and Mortality of COVID-19. Front. Med. 7. https://doi.org/10.3389/fmed.2020.607786

Kim, D., Chen, Z., Zhou, L.-F., Huang, S.-X., 2018. Air pollutants and early origins of respiratory diseases. Chronic Dis Transl Med 4, 75-94. https://doi.org/10.1016/j.cdtm.2018.03.003

Kim, J.W., Park, S., Lim, C.W., Lee, K., Kim, B., 2014. The Role of Air Pollutants in Initiating Liver Disease. Toxicological Research 30, 65-70. https://doi.org/10.5487/TR.2014.30.2.065 
Kirwa, K., Eckert, C.M., Vedal, S., Hajat, A., Kaufman, J.D., 2021. Ambient air pollution and risk of respiratory infection among adults: evidence from the multiethnic study of atherosclerosis (MESA). BMJ Open Respiratory Research 8, e000866. https://doi.org/10.1136/bmjresp-2020-000866

Kudo, E., Song, E., Yockey, L.J., Rakib, T., Wong, P.W., Homer, R.J., Iwasaki, A., 2019. Low ambient humidity impairs barrier function and innate resistance against influenza infection. PNAS 116, 10905-10910. https://doi.org/10.1073/pnas.1902840116

Kumar, G., Kumar, R.R., 2020. A correlation study between meteorological parameters and COVID-19 pandemic in Mumbai, India. Diabetes \& Metabolic Syndrome: Clinical Research \& Reviews 14, 17351742. https://doi.org/10.1016/j.dsx.2020.09.002

Kumar, S., 2020. Effect of meteorological parameters on spread of COVID-19 in India and air quality during lockdown. Sci Total Environ 745, 141021. https://doi.org/10.1016/j.scitotenv.2020.141021

Kunz, C.U., Jörgens, S., Bretz, F., Stallard, N., Lancker, K.V., Xi, D., Zohar, S., Gerlinger, C., Friede, T., 2020. Clinical Trials Impacted by the COVID-19 Pandemic: Adaptive Designs to the Rescue? Statistics in Biopharmaceutical Research 12, 461-477. https://doi.org/10.1080/19466315.2020.1799857

Kurt, O.K., Zhang, J., Pinkerton, K.E., 2016. Pulmonary Health Effects of Air Pollution. Curr Opin Pulm Med 22, 138-143. https://doi.org/10.1097/MCP.0000000000000248

Kyung, S.Y., Jeong, S.H., 2020. Particulate-Matter Related Respiratory Diseases. Tuberc Respir Dis (Seoul) 83, 116-121. https://doi.org/10.4046/trd.2019.0025

Larsen, J.R., Martin, M.R., Martin, J.D., Kuhn, P., Hicks, J.B., 2020. Modeling the Onset of Symptoms of COVID-19. Front. Public Health 8. https://doi.org/10.3389/fpubh.2020.00473

Laumbach, R.J., Kipen, H.M., 2012. Respiratory Health Effects of Air Pollution: Update on Biomass Smoke and Traffic Pollution. J Allergy Clin Immunol 129, 3-13. https://doi.org/10.1016/j.jaci.2011.11.021

LaVoy, E.C.P., McFarlin, B.K., Simpson, R.J., 2011. Immune Responses to Exercising in a Cold Environment. Wilderness \& Environmental Medicine 22, 343-351.

https://doi.org/10.1016/j.wem.2011.08.005

Lee, A., Kinney, P., Chillrud, S., Jack, D., 2015. A Systematic Review of Innate Immunomodulatory Effects of Household Air Pollution Secondary to the Burning of Biomass Fuels. Annals of Global Health 81, 368. https://doi.org/10.1016/j.aogh.2015.08.006

Li, C., Bosch, C., Kang, S., Andersson, A., Chen, P., Zhang, Q., Cong, Z., Chen, B., Qin, D., Gustafsson, Ö., 2016. Sources of black carbon to the Himalayan-Tibetan Plateau glaciers. Nature Communications 7 , 12574. https://doi.org/10.1038/ncomms 12574 
Li, H., Xu, X.-L., Dai, D.-W., Huang, Z.-Y., Ma, Z., Guan, Y.-J., 2020. Air pollution and temperature are associated with increased COVID-19 incidence: A time series study. International Journal of Infectious Diseases 97, 278-282. https://doi.org/10.1016/j.jiji.2020.05.076

Li, P., Wang, Y., Peppelenbosch, M.P., Ma, Z., Pan, Q., 2021. Systematically comparing COVID-19 with the 2009 influenza pandemic for hospitalized patients. Int $\mathrm{J}$ Infect Dis 102, 375-380.

https://doi.org/10.1016/j.ijid.2020.11.127

Li, R., Gong, J., Chen, L., Wang, Z., 2015. Estimating Ground-Level PM2.5 Using Fine-Resolution Satellite Data in the Megacity of Beijing, China. Aerosol Air Qual. Res. 15, 1347-1356.

https://doi.org/10.4209/aaqr.2015.01.0009

Lin, S., Wei, D., Sun, Y., Chen, K., Yang, L., Liu, B., Huang, Q., Paoliello, M.M.B., Li, H., Wu, S., 2020. Regionspecific air pollutants and meteorological parameters influence COVID-19: A study from mainland China. Ecotoxicology and Environmental Safety 204, 111035. https://doi.org/10.1016/j.ecoenv.2020.111035

Liu, B., Taioli, E., 2015. Seasonal Variations of Complete Blood Count and Inflammatory Biomarkers in the US Population - Analysis of NHANES Data. PLoS One 10. https://doi.org/10.1371/journal.pone.0142382

Liu, H., Fan, X., Wang, N., Zhang, Y., Yu, J., 2017. Exacerbating effects of PM2.5 in OVA-sensitized and challenged mice and the expression of TRPA1 and TRPV1 proteins in lungs. Journal of Asthma 54, 807817. https://doi.org/10.1080/02770903.2016.1266495

Liu, H., Liu, S., Xue, B., Lv, Z., Meng, Z., Yang, X., Xue, T., Yu, Q., He, K., 2018. Ground-level ozone pollution and its health impacts in China. Atmospheric Environment 173, 223-230.

https://doi.org/10.1016/j.atmosenv.2017.11.014

Liu, J., Zhou, J., Yao, J., Zhang, X., Li, L., Xu, X., He, X., Wang, B., Fu, S., Niu, T., Yan, J., Shi, Y., Ren, X., Niu, J., Zhu, W., Li, S., Luo, B., Zhang, K., 2020b. Impact of meteorological factors on the COVID-19 transmission: A multi-city study in China. Science of The Total Environment 726, 138513. https://doi.org/10.1016/j.scitotenv.2020.138513

Liu, Q., Tan, Z.-M., Sun, J., Hou, Y., Fu, C., Wu, Z., 2020c. Changing rapid weather variability increases influenza epidemic risk in a warming climate. Environ. Res. Lett. 15, 044004.

https://doi.org/10.1088/1748-9326/ab70bc

Liu, T., Hu, J., Xiao, J., He, G., Kang, M., Rong, Z., Lin, L., Zhong, H., Huang, Q., Deng, A., Zeng, W., Tan, X., Zeng, S., Zhu, Z., Li, J., Gong, D., Wan, D., Chen, S., Guo, L., Li, Y., Sun, L., Liang, W., Song, T., He, J., Ma, W., 2020a. Time-varying transmission dynamics of Novel Coronavirus Pneumonia in China. bioRxiv 2020.01.25.919787. https://doi.org/10.1101/2020.01.25.919787

Liu, Yanli, Sun, W., Guo, Y., Chen, L., Zhang, L., Zhao, S., Long, D., Yu, L., 2020d. Association between platelet parameters and mortality in coronavirus disease 2019: Retrospective cohort study. Platelets 1-7. 
https://doi.org/10.1080/09537104.2020.1754383

Liu, Yansui, Zhou, Y., Lu, J., 2020e. Exploring the relationship between air pollution and meteorological conditions in China under environmental governance. Sci Rep 10, 14518.

https://doi.org/10.1038/s41598-020-71338-7

Logan, J.A., Prather, M.J., Wofsy, S.C., McElroy, M.B., 1981. Tropospheric chemistry: A global perspective. Journal of Geophysical Research: Oceans 86, 7210-7254. https://doi.org/10.1029/JC086iC08p07210

Lowen, A.C., Mubareka, S., Steel, J., Palese, P., 2007. Influenza Virus Transmission Is Dependent on Relative Humidity and Temperature. PLOS Pathogens 3, e151.

https://doi.org/10.1371/journal.ppat.0030151

Lytle, C.D., Sagripanti, J.-L., 2005. Predicted Inactivation of Viruses of Relevance to Biodefense by Solar Radiation. Journal of Virology 79, 14244-14252. https://doi.org/10.1128/JVI.79.22.14244-14252.2005

Ma, Y., Cheng, B., Shen, J., Wang, H., Feng, F., Zhang, Y., Jiao, H., 2021. Association between environmental factors and COVID-19 in Shanghai, China. Environ Sci Pollut Res Int 1-9.

https://doi.org/10.1007/s11356-021-13834-5

Ma, Y., Zhao, Y., Liu, J., He, X., Wang, B., Fu, S., Yan, J., Niu, J., Zhou, J., Luo, B., 2020. Effects of temperature variation and humidity on the death of COVID-19 in Wuhan, China. Science of The Total Environment 724, 138226. https://doi.org/10.1016/j.scitotenv.2020.138226

Maaoui, C., Pruski, A., 2008. A comparative study of SVM kernel applied to emotion recognition from physiological signals, in: 2008 5th International Multi-Conference on Systems, Signals and Devices. Presented at the 2008 5th International Multi-Conference on Systems, Signals and Devices, pp. 1-6. https://doi.org/10.1109/SSD.2008.4632891

Mahapatra, P.S., Puppala, S.P., Adhikary, B., Shrestha, K.L., Dawadi, D.P., Paudel, S.P., Panday, A.K., 2019. Air quality trends of the Kathmandu Valley: A satellite, observation and modeling perspective. Atmospheric Environment 201, 334-347. https://doi.org/10.1016/j.atmosenv.2018.12.043

Manisalidis, I., Stavropoulou, E., Stavropoulos, A., Bezirtzoglou, E., 2020. Environmental and Health Impacts of Air Pollution: A Review. Front Public Health 8. https://doi.org/10.3389/fpubh.2020.00014

Mansouri Daneshvar, M.R., Ebrahimi, M., Sadeghi, A., Mahmoudzadeh, A., 2021. Climate effects on the COVID-19 outbreak: a comparative analysis between the UAE and Switzerland. Model. Earth Syst. Environ. https://doi.org/10.1007/s40808-021-01110-x

Matthew, O.J., Eludoyin, A.O., Oluwadiya, K.S., 2021. Spatio-temporal variations in COVID-19 in relation to the global climate distribution and fluctuations. Spatial and Spatio-temporal Epidemiology 37, 100417. https://doi.org/10.1016/j.sste.2021.100417 
Mecenas, P., Bastos, R.T. da R.M., Vallinoto, A.C.R., Normando, D., 2020. Effects of temperature and humidity on the spread of COVID-19: A systematic review. PLOS ONE 15, e0238339.

https://doi.org/10.1371/journal.pone.0238339

Mehmood, K., Bao, Y., Abrar, M.M., Petropoulos, G.P., Saifullah, Soban, A., Saud, S., Khan, Z.A., Khan, S.M., Fahad, S., 2021. Spatiotemporal variability of COVID-19 pandemic in relation to air pollution, climate and socioeconomic factors in Pakistan. Chemosphere 271, 129584.

https://doi.org/10.1016/j.chemosphere.2021.129584

Mehta, S., Shin, H., Burnett, R., North, T., Cohen, A.J., 2013. Ambient particulate air pollution and acute lower respiratory infections: a systematic review and implications for estimating the global burden of disease. Air Qual Atmos Health 6, 69-83. https://doi.org/10.1007/s11869-011-0146-3

Mele, M., Magazzino, C., Schneider, N., Strezov, V., 2021. NO2 levels as a contributing factor to COVID-19 deaths: The first empirical estimate of threshold values. Environmental Research 194, 110663. https://doi.org/10.1016/j.envres.2020.110663

Menebo, M.M., 2020. Temperature and precipitation associate with Covid-19 new daily cases: A correlation study between weather and Covid-19 pandemic in Oslo, Norway. Science of The Total Environment 737, 139659. https://doi.org/10.1016/j.scitotenv.2020.139659

Mollalo, A., Vahedi, B., Rivera, K.M., 2020. GIS-based spatial modeling of COVID-19 incidence rate in the continental United States. Science of The Total Environment 728, 138884.

https://doi.org/10.1016/j.scitotenv.2020.138884

Moniruzzam, M., Roy, A., Bhatt, C.M., Gupta, A., An, N.T.T., Hassan, M.R., 2018. Impact Analysis of Urbanization on Land Use Land Cover Change for Khulna City, Bangladesh using Temporal Landsat Imagery. Int. Arch. Photogramm. Remote Sens. Spatial Inf. Sci. XLII-5, 757-760.

https://doi.org/10.5194/isprs-archives-XLII-5-757-2018

Moore, M., Little, P., 2007. Humidified air inhalation for treating croup: a systematic review and metaanalysis. Family Practice 24, 295-301. https://doi.org/10.1093/fampra/cmm022

Moriyama, M., Ichinohe, T., 2019. High ambient temperature dampens adaptive immune responses to influenza A virus infection. PNAS 116, 3118-3125. https://doi.org/10.1073/pnas.1815029116

Munawer, M.E., 2018. Human health and environmental impacts of coal combustion and postcombustion wastes. Journal of Sustainable Mining 17, 87-96.

https://doi.org/10.1016/j.jsm.2017.12.007

Nanda, C., Kant, Y., Gupta, A., Mitra, D., 2018. Spatio-Temporal Distribution of Pollutant Trace Gases During Diwali Over India. ISPRS Ann. Photogramm. Remote Sens. Spatial Inf. Sci. IV-5, 339-350. https://doi.org/10.5194/isprs-annals-IV-5-339-2018 
Naqvi, H.R., Datta, M., Mutreja, G., Siddiqui, M.A., Naqvi, D.F., Naqvi, A.R., 2021. Improved air quality and associated mortalities in India under COVID-19 lockdown. Environ Pollut 268, 115691.

https://doi.org/10.1016/j.envpol.2020.115691

Nicholson, L.B., 2016. The immune system. Essays Biochem 60, 275-301.

https://doi.org/10.1042/EBC20160017

Nigam, R., Pandya, K., Luis, A.J., Sengupta, R., Kotha, M., 2021. Positive effects of COVID-19 lockdown on air quality of industrial cities (Ankleshwar and Vapi) of Western India. Sci Rep 11, 4285.

https://doi.org/10.1038/s41598-021-83393-9

Nottmeyer, L.N., Sera, F., 2021. Influence of temperature, and of relative and absolute humidity on COVID19 incidence in England - A multi-city time-series study. Environ Res 196, 110977.

https://doi.org/10.1016/j.envres.2021.110977

Nuvolone, D., Petri, D., Voller, F., 2018. The effects of ozone on human health. Environ Sci Pollut Res 25, 8074-8088. https://doi.org/10.1007/s11356-017-9239-3

Oliveiros, B., Caramelo, L., Ferreira, N.C., Caramelo, F., 2020. Role of temperature and humidity in the modulation of the doubling time of COVID-19 cases. medRxiv 2020.03.05.20031872.

https://doi.org/10.1101/2020.03.05.20031872

Orru, H., Ebi, K.L., Forsberg, B., 2017. The Interplay of Climate Change and Air Pollution on Health. Curr Envir Health Rpt 4, 504-513. https://doi.org/10.1007/s40572-017-0168-6

Pan, Y.-P., Zhu, X.-Y., Tian, S.-L., Wang, L.-L., Zhang, G.-Z., Zhou, Y.-B., Xu, P., Hu, B., Wang, Y.-S., 2017. Wet deposition and scavenging ratio of air pollutants during an extreme rainstorm in the North China Plain. Atmospheric and Oceanic Science Letters 10, 348-353.

https://doi.org/10.1080/16742834.2017.1343084

Pandey, S.K., Vinoj, V., Landu, K., Babu, S.S., 2017. Declining pre-monsoon dust loading over South Asia: Signature of a changing regional climate. Sci Rep 7, 16062. https://doi.org/10.1038/s41598-017-16338W

Pani, S.K., Lin, N.-H., RavindraBabu, S., 2020. Association of COVID-19 pandemic with meteorological parameters over Singapore. Science of The Total Environment 740, 140112.

https://doi.org/10.1016/j.scitotenv.2020.140112

Panofsky, H.A., Prasad, B., 1967. The Effect of Meteorological Factors on Air Pollution in a Narrow Valley. Journal of Applied Meteorology and Climatology 6, 493-499. https://doi.org/10.1175/15200450(1967)006<0493:TEOMFO>2.0.CO;2

Pansini, R., Fornacca, D., 2020. COVID-19 higher induced mortality in Chinese regions with lower air quality. medRxiv 2020.04.04.20053595. https://doi.org/10.1101/2020.04.04.20053595 
Paulin, L., Hansel, N., 2016. Particulate air pollution and impaired lung function. F1000Res 5, 201. https://doi.org/10.12688/f1000research.7108.1

Paunescu, A.-C., Casas, M., Ferrero, A., Pañella, P., Bougas, N., Beydon, N., Just, J., Lezmi, G., Sunyer, J., Ballester, F., Momas, I., 2019. Associations of black carbon with lung function and airway inflammation in schoolchildren. Environment International 131, 104984. https://doi.org/10.1016/j.envint.2019.104984

Perlman, S., 2020. Another Decade, Another Coronavirus. New England Journal of Medicine 382, 760762. https://doi.org/10.1056/NEJMe2001126

Peters, A., Dockery, D.W., Muller, J.E., Mittleman, M.A., 2001. Increased Particulate Air Pollution and the Triggering of Myocardial Infarction. Circulation 103, 2810-2815.

https://doi.org/10.1161/01.CIR.103.23.2810

Pica, N., Bouvier, N.M., 2012. Environmental factors affecting the transmission of respiratory viruses. Curr Opin Virol 2, 90-95. https://doi.org/10.1016/j.coviro.2011.12.003

Power, G.G., 1968. Solubility of 02 and $\mathrm{CO}$ in blood and pulmonary and placental tissue. Journal of Applied Physiology 24, 468-474. https://doi.org/10.1152/jappl.1968.24.4.468

Prabhu, V., Soni, A., Madhwal, S., Gupta, A., Sundriyal, S., Shridhar, V., Sreekanth, V., Mahapatra, P.S., 2020. Black carbon and biomass burning associated high pollution episodes observed at Doon valley in the foothills of the Himalayas. Atmospheric Research 243, 105001.

https://doi.org/10.1016/j.atmosres.2020.105001

Price, R.H.M., Graham, C., Ramalingam, S., 2019. Association between viral seasonality and meteorological factors. Scientific Reports 9, 929. https://doi.org/10.1038/s41598-018-37481-y

Qi, H., Xiao, S., Shi, R., Ward, M.P., Chen, Y., Tu, W., Su, Q., Wang, W., Wang, X., Zhang, Z., 2020. COVID-19 transmission in Mainland China is associated with temperature and humidity: A time-series analysis. Science of The Total Environment 728, 138778. https://doi.org/10.1016/j.scitotenv.2020.138778

Qin, Y.-G., Yi, C., Dong, G.-L., Min, J.-Z., 2020. Investigating the influence of meteorological factors on particulate matters: A case study based on path analysis. Energy \& Environment 31, 479-491. https://doi.org/10.1177/0958305X19876696

Rendana, M., 2020. Impact of the wind conditions on COVID-19 pandemic: A new insight for direction of the spread of the virus. Urban Clim 34, 100680. https://doi.org/10.1016/j.uclim.2020.100680

Roldán-Henao, N., Hoyos, C.D., Herrera-Mejía, L., Isaza, A., 2020. An Investigation of the Precipitation Net Effect on the Particulate Matter Concentration in a Narrow Valley: Role of Lower-Troposphere Stability. Journal of Applied Meteorology and Climatology 59, 401-426. https://doi.org/10.1175/JAMC-D-180313.1 
Rosario, D.K.A., Mutz, Y.S., Bernardes, P.C., Conte-Junior, C.A., 2020. Relationship between COVID-19 and weather: Case study in a tropical country. International Journal of Hygiene and Environmental Health 229, 113587. https://doi.org/10.1016/j.ijheh.2020.113587

Rosenthal, F.S., Kuisma, M., Lanki, T., Hussein, T., Boyd, J., Halonen, J.I., Pekkanen, J., 2013. Association of ozone and particulate air pollution with out-of-hospital cardiac arrest in Helsinki, Finland: Evidence for two different etiologies. Journal of Exposure Science \& Environmental Epidemiology 23, 281-288. https://doi.org/10.1038/jes.2012.121

Rousta, I., Olafsson, H., Moniruzzaman, M., Zhang, H., Liou, Y.-A., Mushore, T.D., Gupta, A., 2020. Impacts of Drought on Vegetation Assessed by Vegetation Indices and Meteorological Factors in Afghanistan. Remote Sensing 12, 2433. https://doi.org/10.3390/rs12152433

Rume, T., Islam, S.M.D.-U., 2020. Environmental effects of COVID-19 pandemic and potential strategies of sustainability. Heliyon 6. https://doi.org/10.1016/j.heliyon.2020.e04965

Runkle, J.D., Sugg, M.M., Leeper, R.D., Rao, Y., Matthews, J.L., Rennie, J.J., 2020. Short-term effects of specific humidity and temperature on COVID-19 morbidity in select US cities. Sci Total Environ 740, 140093. https://doi.org/10.1016/j.scitotenv.2020.140093

Saadat, S., Rawtani, D., Hussain, C.M., 2020. Environmental perspective of COVID-19. Science of The Total Environment 728, 138870. https://doi.org/10.1016/j.scitotenv.2020.138870

Şahin, M., 2020. Impact of weather on COVID-19 pandemic in Turkey. Science of The Total Environment 728, 138810. https://doi.org/10.1016/j.scitotenv.2020.138810

Saikawa, E., Panday, A., Kang, S., Gautam, R., Zusman, E., Cong, Z., Somanathan, E., Adhikary, B., 2019. Air Pollution in the Hindu Kush Himalaya, in: Wester, P., Mishra, A., Mukherji, A., Shrestha, A.B. (Eds.), The Hindu Kush Himalaya Assessment: Mountains, Climate Change, Sustainability and People. Springer International Publishing, Cham, pp. 339-387. https://doi.org/10.1007/978-3-319-92288-1_10

Sajadi, M.M., Habibzadeh, P., Vintzileos, A., Shokouhi, S., Miralles-Wilhelm, F., Amoroso, A., 2020. Temperature, Humidity, and Latitude Analysis to Estimate Potential Spread and Seasonality of Coronavirus Disease 2019 (COVID-19). JAMA Netw Open 3, e2011834.

https://doi.org/10.1001/jamanetworkopen.2020.11834

Saliba, N.A., El Jam, F., El Tayar, G., Obeid, W., Roumie, M., 2010. Origin and variability of particulate matter (PM10 and PM2.5) mass concentrations over an Eastern Mediterranean city. Atmospheric Research 97, 106-114. https://doi.org/10.1016/j.atmosres.2010.03.011

Sangkham, S., Thongtip, S., Vongruang, P., 2021. Influence of air pollution and meteorological factors on the spread of COVID-19 in the Bangkok Metropolitan Region and air quality during the outbreak. Environ Res 197, 111104. https://doi.org/10.1016/j.envres.2021.111104 
Sario, M.D., Katsouyanni, K., Michelozzi, P., 2013. Climate change, extreme weather events, air pollution and respiratory health in Europe. European Respiratory Journal 42, 826-843.

https://doi.org/10.1183/09031936.00074712

Sarkodie, S.A., Owusu, P.A., 2020. Impact of meteorological factors on COVID-19 pandemic: Evidence from top 20 countries with confirmed cases. Environmental Research 191, 110101. https://doi.org/10.1016/j.envres.2020.110101

Sathian, B., Asim, M., Banerjee, I., Pizarro, A.B., Roy, B., van Teijlingen, E.R., do Nascimento, I.J.B., Alhamad, H.K., 2020. Impact of COVID-19 on clinical trials and clinical research: A systematic review. Nepal J Epidemiol 10, 878-887. https://doi.org/10.3126/nje.v10i3.31622

Schmidt, C.W., 2011. Black Carbon: The Dark Horse of Climate Change Drivers. Environ Health Perspect 119, A172-A175.

Schraufnagel, D.E., Balmes, J.R., Cowl, C.T., Matteis, S.D., Jung, S.-H., Mortimer, K., Perez-Padilla, R., Rice, M.B., Riojas-Rodriguez, H., Sood, A., Thurston, G.D., To, T., Vanker, A., Wuebbles, D.J., 2019. Air Pollution and Noncommunicable Diseases: A Review by the Forum of International Respiratory Societies' Environmental Committee, Part 1: The Damaging Effects of Air Pollution. CHEST 155, 409-416. https://doi.org/10.1016/j.chest.2018.10.042

Segersson, D., Eneroth, K., Gidhagen, L., Johansson, C., Omstedt, G., Engström Nylén, A., Forsberg, B., 2017. Health Impact of PM10, PM2.5 and Black Carbon Exposure Due to Different Source Sectors in Stockholm, Gothenburg and Umea, Sweden. Int J Environ Res Public Health 14. https://doi.org/10.3390/ijerph14070742

Selcuk, M., Gormus, S., Guven, M., 2021. Impact of Weather Parameters and Population Density on the COVID-19 Transmission: Evidence from 81 Provinces of Turkey. Earth Syst Environ 5, 87-100. https://doi.org/10.1007/s41748-020-00197-z

Seo, J., Park, D.-S.R., Kim, J.Y., Youn, D., Lim, Y.B., Kim, Y., 2018. Effects of meteorology and emissions on urban air quality: a quantitative statistical approach to long-term records (1999-2016) in Seoul, South Korea. Atmos. Chem. Phys. 18, 16121-16137. https://doi.org/10.5194/acp-18-16121-2018

Shahri, M.K., Niazkar, H.R., Rad, F., 2021. COVID-19 and hematology findings based on the current evidences: A puzzle with many missing pieces. International Journal of Laboratory Hematology 43, 160168. https://doi.org/10.1111/ijlh.13412

Shakil, M.H., Munim, Z.H., Tasnia, M., Sarowar, S., 2020. COVID-19 and the environment: A critical review and research agenda. Science of The Total Environment 745, 141022.

https://doi.org/10.1016/j.scitotenv.2020.141022 
Sharma, G.D., Bansal, S., Yadav, A., Jain, M., Garg, I., 2021. Meteorological factors, COVID-19 cases, and deaths in top 10 most affected countries: an econometric investigation. Environ Sci Pollut Res. https://doi.org/10.1007/s11356-021-12668-5

Shi, P., Dong, Y., Yan, H., Zhao, C., Li, X., Liu, W., He, M., Tang, S., Xi, S., 2020. Impact of temperature on the dynamics of the COVID-19 outbreak in China. Science of The Total Environment 728, 138890.

https://doi.org/10.1016/j.scitotenv.2020.138890

Shukla, J.B., Misra, A.K., Sundar, S., Naresh, R., 2008. Effect of rain on removal of a gaseous pollutant and two different particulate matters from the atmosphere of a city. Mathematical and Computer Modelling 48, 832-844. https://doi.org/10.1016/j.mcm.2007.10.016

Sil, A., Kumar, V.N., 2020. Does weather affect the growth rate of COVID-19, a study to comprehend transmission dynamics on human health. Journal of Safety Science and Resilience 1, 3-11.

https://doi.org/10.1016/j.jnlssr.2020.06.004

Singh, R.P., Chauhan, A., 2020. Impact of lockdown on air quality in India during COVID-19 pandemic. Air Qual Atmos Health 1-8. https://doi.org/10.1007/s11869-020-00863-1

Smola, A.J., Schölkopf, B., 2004. A tutorial on support vector regression. Statistics and Computing 14, 199-222. https://doi.org/10.1023/B:STC0.0000035301.49549.88

Song, S., Zhan, Z., Long, Z., Zhang, J., Yao, L., 2011. Comparative study of SVM methods combined with voxel selection for object category classification on fMRI data. PLoS One 6, e17191.

https://doi.org/10.1371/journal.pone.0017191

Spekreijse, D., Bouma, A., Koch, G., Stegeman, A., 2013. Quantification of dust-borne transmission of highly pathogenic avian influenza virus between chickens. Influenza Other Respir Viruses 7, 132-138. https://doi.org/10.1111/j.1750-2659.2012.00362.x

Steffens, I., 2020. A hundred days into the coronavirus disease (COVID-19) pandemic. Eurosurveillance 25, 2000550. https://doi.org/10.2807/1560-7917.ES.2020.25.14.2000550

Suhaimi, N.F., Jalaludin, J., 2015. Biomarker as a research tool in linking exposure to air particles and respiratory health. Biomed Res Int 2015, 962853. https://doi.org/10.1155/2015/962853

Suhaimi, N.F., Jalaludin, J., Latif, M.T., 2020. Demystifying a Possible Relationship between COVID-19, Air Quality and Meteorological Factors: Evidence from Kuala Lumpur, Malaysia. Aerosol Air Qual. Res. 20, 1520-1529. https://doi.org/10.4209/aaqr.2020.05.0218

Sun, Z., Thilakavathy, K., Kumar, S.S., He, G., Liu, S.V., 2020. Potential Factors Influencing Repeated SARS Outbreaks in China. International Journal of Environmental Research and Public Health 17, 1633. https://doi.org/10.3390/ijerph17051633 
Suryadhi, M.A.H., Abudureyimu, K., Kashima, S., Yorifuji, T., 2020. Nitrogen dioxide and acute respiratory tract infections in children in Indonesia. Arch Environ Occup Health 75, 274-280.

https://doi.org/10.1080/19338244.2019.1631245

Tan, J., Mu, L., Huang, J., Yu, S., Chen, B., Yin, J., 2005. An initial investigation of the association between the SARS outbreak and weather: with the view of the environmental temperature and its variation. $J$ Epidemiol Community Health 59, 186-192. https://doi.org/10.1136/jech.2004.020180

Tang, S., Mao, Y., Jones, R.M., Tan, Q., Ji, J.S., Li, N., Shen, J., Lv, Y., Pan, L., Ding, P., Wang, X., Wang, Y., Maclntyre, C.R., Shi, X., 2020. Aerosol transmission of SARS-CoV-2? Evidence, prevention and control. Environment International 144, 106039. https://doi.org/10.1016/j.envint.2020.106039

Tellier, R., 2006. Review of aerosol transmission of influenza A virus. Emerg Infect Dis 12, 1657-1662. https://doi.org/10.3201/eid1211.060426

Thompson, A.M., 1992. The Oxidizing Capacity of the Earth's Atmosphere: Probable Past and Future Changes. Science 256, 1157-1165. https://doi.org/10.1126/science.256.5060.1157

Thurston, G.D., Kipen, H., Annesi-Maesano, I., Balmes, J., Brook, R.D., Cromar, K., De Matteis, S., Forastiere, F., Forsberg, B., Frampton, M.W., Grigg, J., Heederik, D., Kelly, F.J., Kuenzli, N., Laumbach, R., Peters, A., Rajagopalan, S.T., Rich, D., Ritz, B., Samet, J.M., Sandstrom, T., Sigsgaard, T., Sunyer, J., Brunekreef, B., 2017. A joint ERS/ATS policy statement: what constitutes an adverse health effect of air pollution? An analytical framework. Eur Respir J 49. https://doi.org/10.1183/13993003.00419-2016

Tien Bui, D., Pradhan, B., Lofman, O., Revhaug, I., 2012. Landslide Susceptibility Assessment in Vietnam Using Support Vector Machines, Decision Tree, and Naïve Bayes Models [WWW Document]. Mathematical Problems in Engineering. https://doi.org/10.1155/2012/974638

Tobias, A., Karanasiou, A., Reche, C., Amato, F., Alastuey, A., Querol, X., 2014. Effects of black carbon on respiratory health in the city of Barcelona. European Respiratory Journal 44.

Tosepu, R., Gunawan, J., Effendy, D.S., Ahmad, L.O.A.I., Lestari, H., Bahar, H., Asfian, P., 2020. Correlation between weather and Covid-19 pandemic in Jakarta, Indonesia. Science of The Total Environment 725, 138436. https://doi.org/10.1016/j.scitotenv.2020.138436

Turner, M.C., Jerrett, M., Pope, C.A., Krewski, D., Gapstur, S.M., Diver, W.R., Beckerman, B.S., Marshall, J.D., Su, J., Crouse, D.L., Burnett, R.T., 2015. Long-Term Ozone Exposure and Mortality in a Large Prospective Study. Am J Respir Crit Care Med 193, 1134-1142. https://doi.org/10.1164/rccm.201508-16330C

Tuttle, K.R., 2020. Impact of the COVID-19 pandemic on clinical research. Nature Reviews Nephrology 16, 562-564. https://doi.org/10.1038/s41581-020-00336-9

Urman, R., McConnell, R., Islam, T., Avol, E.L., Lurmann, F.W., Vora, H., Linn, W.S., Rappaport, E.B., Gilliland, F.D., Gauderman, W.J., 2014. Associations of children's lung function with ambient air pollution: joint 
effects of regional and near-roadway pollutants. Thorax 69, 540-547. https://doi.org/10.1136/thoraxjnl2012-203159

VALAVANIDIS, A., FIOTAKIS, K., VLACHOGIANNI, T., 2008. Airborne Particulate Matter and Human Health: Toxicological Assessment and Importance of Size and Composition of Particles for Oxidative Damage and Carcinogenic Mechanisms. Journal of Environmental Science and Health, Part C 26, 339-362. https://doi.org/10.1080/10590500802494538

Valko, M., Leibfritz, D., Moncol, J., Cronin, M.T.D., Mazur, M., Telser, J., 2007. Free radicals and antioxidants in normal physiological functions and human disease. The International Journal of Biochemistry \& Cell Biology 39, 44-84. https://doi.org/10.1016/j.biocel.2006.07.001

Vapnik, V., Golowich, S.E., Smola, A.J., 1997. Support Vector Method for Function Approximation, Regression Estimation and Signal Processing 7.

Vapnik, V.N., 1995. The Nature of Statistical Learning Theory. Springer New York, New York, NY. https://doi.org/10.1007/978-1-4757-2440-0

Vautard, R., Builtjes, P.H.J., Thunis, P., Cuvelier, C., Bedogni, M., Bessagnet, B., Honoré, C., Moussiopoulos, N., Pirovano, G., Schaap, M., 2007. Evaluation and intercomparison of Ozone and PM10 simulations by several chemistry transport models over four European cities within the CityDelta project. Atmospheric Environment 41, 173-188. https://doi.org/10.1016/j.atmosenv.2006.07.039

Venter, Z.S., Aunan, K., Chowdhury, S., Lelieveld, J., 2020. COVID-19 lockdowns cause global air pollution declines. PNAS 117, 18984-18990. https://doi.org/10.1073/pnas.2006853117

Wang, C., Horby, P.W., Hayden, F.G., Gao, G.F., 2020a. A novel coronavirus outbreak of global health concern. The Lancet 395, 470-473. https://doi.org/10.1016/S0140-6736(20)30185-9

Wang, J., Ogawa, S., 2015. Effects of Meteorological Conditions on PM2.5 Concentrations in Nagasaki, Japan. Int J Environ Res Public Health 12, 9089-9101. https://doi.org/10.3390/ijerph120809089

Wang, J., Yu, A., Yang, L., Fang, C., 2019. Research on Organic Carbon and Elemental Carbon Distribution Characteristics and Their Influence on Fine Particulate Matter (PM2.5) in Changchun City. Environments 6, 21. https://doi.org/10.3390/environments6020021

Wang, M., Jiang, A., Gong, L., Luo, L., Guo, W., Li, Chuyi, Zheng, J., Li, Chaoyong, Yang, B., Zeng, J., Chen, Y., Zheng, K., Li, H., 2020b. Temperature significant change COVID-19 Transmission in 429 cities. medRxiv 2020.02.22.20025791. https://doi.org/10.1101/2020.02.22.20025791

Wang, Q., Su, M., 2020. A preliminary assessment of the impact of COVID-19 on environment - A case study of China. Science of The Total Environment 728, 138915.

https://doi.org/10.1016/j.scitotenv.2020.138915 
Wang, Y., Wang, Yuyi, Chen, Y., Qin, Q., 2020c. Unique epidemiological and clinical features of the emerging 2019 novel coronavirus pneumonia (COVID-19) implicate special control measures. Journal of Medical Virology 92, 568-576. https://doi.org/10.1002/jmv.25748

White, M.P., Alcock, I., Grellier, J., Wheeler, B.W., Hartig, T., Warber, S.L., Bone, A., Depledge, M.H., Fleming, L.E., 2019. Spending at least 120 minutes a week in nature is associated with good health and wellbeing. Scientific Reports 9, 7730. https://doi.org/10.1038/s41598-019-44097-3

Winiger, P., Andersson, A., Eckhardt, S., Stohl, A., Gustafsson, Ö., 2016. The sources of atmospheric black carbon at a European gateway to the Arctic. Nature Communications 7, 12776. https://doi.org/10.1038/ncomms12776

Wu, J.-Z., Ge, D.-D., Zhou, L.-F., Hou, L.-Y., Zhou, Y., Li, Q.-Y., 2018a. Effects of particulate matter on allergic respiratory diseases. Chronic Diseases and Translational Medicine, Special Issue: Air Pollution and Chronic Respiratory Diseases 4, 95-102. https://doi.org/10.1016/j.cdtm.2018.04.001

Wu, X., Nethery, R.C., Sabath, M.B., Braun, D., Dominici, F., 2020. Air pollution and COVID-19 mortality in the United States: Strengths and limitations of an ecological regression analysis. Science Advances 6, eabd4049. https://doi.org/10.1126/sciadv.abd4049

Wu, Y., Liu, J., Zhai, J., Cong, L., Wang, Y., Ma, W., Zhang, Z., Li, C., 2018b. Comparison of dry and wet deposition of particulate matter in near-surface waters during summer. PLOS ONE 13, e0199241. https://doi.org/10.1371/journal.pone.0199241

Wu, Z., McGoogan, J.M., 2020. Characteristics of and Important Lessons From the Coronavirus Disease 2019 (COVID-19) Outbreak in China: Summary of a Report of 72314 Cases From the Chinese Center for Disease Control and Prevention. JAMA 323, 1239. https://doi.org/10.1001/jama.2020.2648

Xie, J., Zhu, Y., 2020. Association between ambient temperature and COVID-19 infection in 122 cities from China. Science of The Total Environment 724, 138201. https://doi.org/10.1016/j.scitotenv.2020.138201

Xing, Y.-F., Xu, Y.-H., Shi, M.-H., Lian, Y.-X., 2016. The impact of PM2.5 on the human respiratory system. J Thorac Dis 8, E69-E74. https://doi.org/10.3978/j.issn.2072-1439.2016.01.19

Xu, H., Guinot, B., Ho, S.S.H., Li, Y., Cao, J., Shen, Z., Niu, X., Zhao, Z., Liu, S., Lei, Y., Zhang, Q., Sun, J., 2018a. Evaluation on exposures to particulate matter at a junior secondary school: a comprehensive study on health risks and effective inflammatory responses in Northwestern China. Environ Geochem Health 40, 849-863. https://doi.org/10.1007/s10653-017-0030-7

Xu, X., Liu, X., Ma, S., Xu, Ya, Xu, Ying, Guo, X., Li, D., 2018b. Association of Melatonin Production with Seasonal Changes, Low Temperature, and Immuno-Responses in Hamsters. Molecules 23. https://doi.org/10.3390/molecules23030703 
Yang, G., Liu, Y., Li, X., 2020a. Spatiotemporal distribution of ground-level ozone in China at a city level. Scientific Reports 10, 7229. https://doi.org/10.1038/s41598-020-64111-3

Yang, X., Yang, Q., Wang, Y., Wu, Y., Xu, J., Yu, Y., Shang, Y., 2020b. Thrombocytopenia and its association with mortality in patients with COVID-19. Journal of Thrombosis and Haemostasis 18, 1469-1472. https://doi.org/10.1111/jth.14848

Yekkehkhany, B., Safari, A., Homayouni, S., Hasanlou, M., 2014. A Comparison Study of Different Kernel Functions for Svm-Based Classification of Multi-Temporal Polarimetry Sar Data. Int. Arch. Photogramm. Remote Sens. Spatial Inf. Sci. XL-2/W3, 281-285. https://doi.org/10.5194/isprsarchives-XL-2-W3-2812014

Yuan, J., Wu, Y., Jing, W., Liu, J., Du, M., Wang, Y., Liu, M., 2021. Non-linear correlation between daily new cases of COVID-19 and meteorological factors in 127 countries. Environ Res 193, 110521. https://doi.org/10.1016/j.envres.2020.110521

Zhang, D., Li, Y., Chen, Q., Jiang, Y., Chu, C., Ding, Y., Yu, Y., Fan, Y., Shi, J., Luo, Y., Zhou, W., 2019b. The relationship between air quality and respiratory pathogens among children in Suzhou City. Italian Journal of Pediatrics 45, 123. https://doi.org/10.1186/s13052-019-0702-2

Zhang, H., Wang, Y., Hu, J., Ying, Q., Hu, X.-M., 2015. Relationships between meteorological parameters and criteria air pollutants in three megacities in China. Environmental Research 140, 242-254. https://doi.org/10.1016/j.envres.2015.04.004

Zhang, H., Wang, Z., 2011. Advances in the Study of Black Carbon Effects on Climate. Advances in Climate Change Research 2, 23-30. https://doi.org/10.3724/SP.J.1248.2011.00023

Zhang, J., Chen, Q., Wang, Q., Ding, Z., Sun, H., Xu, Y., 2019c. The acute health effects of ozone and PM2.5 on daily cardiovascular disease mortality: A multi-center time series study in China. Ecotoxicology and Environmental Safety 174, 218-223. https://doi.org/10.1016/j.ecoenv.2019.02.085

Zhang, J. (Jim), Wei, Y., Fang, Z., 2019a. Ozone Pollution: A Major Health Hazard Worldwide. Front. Immunol. 10. https://doi.org/10.3389/fimmu.2019.02518

Zhang, L., Michelangeli, D.V., Taylor, P.A., 2004. Numerical studies of aerosol scavenging by low-level, warm stratiform clouds and precipitation. Atmospheric Environment 38, 4653-4665.

https://doi.org/10.1016/j.atmosenv.2004.05.042

Zhang, Z., Xu, X., Qiao, L., Gong, D., Kim, S.-J., Wang, Y., Mao, R., 2018. Numerical simulations of the effects of regional topography on haze pollution in Beijing. Sci Rep 8, 5504. https://doi.org/10.1038/s41598-018-23880-8

Zhao, Y., Richardson, B., Takle, E., Chai, L., Schmitt, D., Xin, H., 2019. Airborne transmission may have played a role in the spread of 2015 highly pathogenic avian influenza outbreaks in the United States. 
Scientific Reports 9, 11755. https://doi.org/10.1038/s41598-019-47788-z

Zheng, Z., Xu, G., Li, Q., Chen, C., Li, J., 2019. Effect of precipitation on reducing atmospheric pollutant over Beijing. Atmospheric Pollution Research 10, 1443-1453. https://doi.org/10.1016/j.apr.2019.04.001

Zhu, N., Zhang, D., Wang, W., Li, X., Yang, B., Song, J., Zhao, X., Huang, B., Shi, W., Lu, R., Niu, P., Zhan, F., Ma, X., Wang, D., Xu, W., Wu, G., Gao, G.F., Tan, W., 2020a. A Novel Coronavirus from Patients with Pneumonia in China, 2019. N Engl J Med 382, 727-733. https://doi.org/10.1056/NEJMoa2001017

Zhu, Y., Xie, J., Huang, F., Cao, L., 2020b. Association between short-term exposure to air pollution and COVID-19 infection: Evidence from China. Sci Total Environ 727, 138704.

https://doi.org/10.1016/j.scitotenv.2020.138704

Zoran, M.A., Savastru, R.S., Savastru, D.M., Tautan, M.N., 2020. Assessing the relationship between ground levels of ozone (O3) and nitrogen dioxide (NO2) with coronavirus (COVID-19) in Milan, Italy. Science of The Total Environment 740, 140005. https://doi.org/10.1016/j.scitotenv.2020.140005

Zu, Z.Y., Jiang, M.D., Xu, P.P., Chen, W., Ni, Q.Q., Lu, G.M., Zhang, L.J., 2020. Coronavirus Disease 2019 (COVID-19): A Perspective from China. Radiology 200490. https://doi.org/10.1148/radiol.2020200490

Asyary, A., Veruswati, M., 2020. Sunlight exposure increased Covid-19 recovery rates: A study in the central pandemic area of Indonesia. Sci. Total Environ. 729, 139016.

https://doi.org/10.1016/j.scitotenv.2020.139016

Auler, A.C., Cássaro, F.A.M., da Silva, V.O., Pires, L.F., 2020. Evidence that high temperatures and intermediate relative humidity might favor the spread of COVID-19 in tropical climate: A case study for the most affected Brazilian cities. Sci. Total Environ. 729, 139090.

https://doi.org/10.1016/j.scitotenv.2020.139090

Awasthi, A., Sharma, A., Kaur, P., Gugamsetty, B., Kumar, A., 2021. Statistical interpretation of environmental influencing parameters on COVID-19 during the lockdown in Delhi, India. Environ. Dev. Sustain. 23, 8147-8160. https://doi.org/10.1007/s10668-020-01000-9

Barcelo, D., 2020. An environmental and health perspective for COVID-19 outbreak: Meteorology and air quality influence, sewage epidemiology indicator, hospitals disinfection, drug therapies and recommendations. J. Environ. Chem. Eng. 8, 104006. https://doi.org/10.1016/j.jece.2020.104006

Bertuzzo, E., Mari, L., Pasetto, D., Miccoli, S., Casagrandi, R., Gatto, M., Rinaldo, A., 2020. The geography of COVID-19 spread in Italy and implications for the relaxation of confinement measures. Nat. Commun. 11, 1-11. https://doi.org/10.1038/s41467-020-18050-2

Bhattacharjee, A., Kumar, M., Patel, K.K., 2021. When COVID-19 will decline in India? Prediction by combination of recovery and case load rate. Clin. Epidemiol. Glob. Heal. 9, 17-20.

https://doi.org/10.1016/j.cegh.2020.06.004

Page $33 / 37$ 
Ceylan, Z., 2021. Insights into the relationship between weather parameters and COVID-19 outbreak in Lombardy, Italy. Int. J. Healthc. Manag. 14, 255-263. https://doi.org/10.1080/20479700.2020.1858394

Chen, Y., Li, Q., Karimian, H., Chen, X., Li, X., 2021. Spatio-temporal distribution characteristics and influencing factors of COVID-19 in China. Sci. Rep. 11, 1-12. https://doi.org/10.1038/s41598-021-831664

Doğan, B., Ben Jebli, M., Shahzad, K., Farooq, T.H., Shahzad, U., 2020. Investigating the Effects of Meteorological Parameters on COVID-19: Case Study of New Jersey, United States. Environ. Res. 191, 110148. https://doi.org/10.1016/j.envres.2020.110148

Domingo, J.L., Rovira, J., 2020. Effects of air pollutants on the transmission and severity of respiratory viral infections. Environ. Res. 187, 109650. https://doi.org/10.1016/j.envres.2020.109650

Fu, S., Wang, B., Zhou, J., Xu, X., Liu, J., Ma, Y., Li, L., He, X., Li, S., Niu, J., Luo, B., Zhang, K., 2021. Meteorological factors, governmental responses and COVID-19: Evidence from four European countries. Environ. Res. 194, 110596. https://doi.org/10.1016/j.envres.2020.110596

Gorbalenya, A.E., Baker, S.C., Baric, R.S., de Groot, R.J., Drosten, C., Gulyaeva, A.A., Haagmans, B.L., Lauber, C., Leontovich, A.M., Neuman, B.W., Penzar, D., Perlman, S., Poon, L.L.M., Samborskiy, D., Sidorov, I.A., Sola, I., Ziebuhr, J., 2020. Severe acute respiratory syndrome-related coronavirus: The species and its viruses - a statement of the Coronavirus Study Group. bioRxiv.

https://doi.org/10.1101/2020.02.07.937862

Hridoy, A.E.E., Mohiman, M.A., Tusher, S.M.S.H., Nowraj, S.Z.A., Rahman, M.A., 2021. Impact of meteorological parameters on COVID-19 transmission in Bangladesh: a spatiotemporal approach. Theor. Appl. Climatol. 144, 273-285. https://doi.org/10.1007/s00704-021-03535-x

Islam, A.R.M.T., Hasanuzzaman, M., Azad, M.A.K., Salam, R., Toshi, F.Z., Khan, M.S.I., Alam, G.M.M., Ibrahim, S.M., 2021. Effect of meteorological factors on COVID-19 cases in Bangladesh. Environ. Dev. Sustain. 23, 9139-9162. https://doi.org/10.1007/s10668-020-01016-1

Jain, M., Sharma, G.D., Goyal, M., Kaushal, R., Sethi, M., 2021. Econometric analysis of COVID-19 cases, deaths, and meteorological factors in South Asia. Environ. Sci. Pollut. Res. 28, 28518-28534. https://doi.org/10.1007/s11356-021-12613-6

Kaplin, A., Junker, C., Kumar, A., Ribeiro, M.A., Yu, E., Wang, M., Smith, T., Rai, S.N., Bhatnagar, A., 2021. Evidence and magnitude of the effects of meteorological changes on SARS-CoV-2 transmission. PLoS One 16, 1-16. https://doi.org/10.1371/journal.pone.0246167

Karapiperis, C., Kouklis, P., Papastratos, S., Chasapi, A., Ouzounis, C., 2020. Assessment for the seasonality of Covid-19 should focus on ultraviolet radiation and not 'warmer days' 19-20. https://doi.org/10.31219/osf.io/397yg 
Kumar, S., 2020. Effect of meteorological parameters on spread of COVID-19 in India and air quality during lockdown. Sci. Total Environ. 745, 141021. https://doi.org/10.1016/j.scitotenv.2020.141021

Leung, K., Wu, J.T., Liu, D., Leung, G.M., 2020. First-wave COVID-19 transmissibility and severity in China outside Hubei after control measures, and second-wave scenario planning: a modelling impact assessment. Lancet 395, 1382-1393. https://doi.org/10.1016/S0140-6736(20)30746-7

Li, H., Xu, X.L., Dai, D.W., Huang, Z.Y., Ma, Z., Guan, Y.J., 2020. Air pollution and temperature are associated with increased COVID-19 incidence: A time series study. Int. J. Infect. Dis. 97, 278-282. https://doi.org/10.1016/j.ijid.2020.05.076

Lin, S., Wei, D., Sun, Y., Chen, K., Yang, L., Liu, B., Huang, Q., Bastos Paoliello, M.M., Li, H., Wu, S., 2020. Region-specific air pollutants and meteorological parameters influence COVID-19: A study from mainland China. Ecotoxicol. Environ. Saf. 204, 111035. https://doi.org/10.1016/j.ecoenv.2020.111035

Liu, T., Hu, J., Xiao, J., He, G., Kang, M., Rong, Z., Lin, L., Zhong, H., Huang, Q., Deng, A., Zeng, W., Tan, X., Zeng, S., Zhu, Z., Li, J., Gong, D., Wan, D., Chen, S., Guo, L., Li, Y., Sun, L., Liang, W., Song, T., He, J., Ma, W., 2020. Time-varying transmission dynamics of Novel Coronavirus Pneumonia in China. bioRxiv.

https://doi.org/10.1101/2020.01.25.919787

Luo, W., Majumder, M., Liu, D., Poirier, C., Mandl, K., Lipsitch, M., Santillana, M., 2020. The role of absolute humidity on transmission rates of the COVID-19 outbreak. medRxiv 1-7.

https://doi.org/10.1101/2020.02.12.20022467

Oliveiros; , B., Caramelo; L., Ferreira; N.C., F Caramelo, 2020. Role of temperature and humidity in the modulation of the doubling time of COVID-19 cases B. medRxiv 1-13.

https://doi.org/https://doi.org/10.1101/2020.03.05.20031872

Sahafizadeh, E., Sartoli, S., 2020. High temperature has no impact on the reproduction number and new cases of COVID-19 in Bushehr, Iran. J. Travel Med. https://doi.org/10.1101/2020.06.14.20130906

Saraç, S., Koyuncu, M., 2020. The Effect of Weather Conditions and Some Demographic Data on the Confirmed COVID-19 Cases: Analysis for 12 Statistical Regions of Turkey Vakalar I Üzerine Etkisi: Türkiye ' nin 12 I statistik Bölgesi Analizi 35, 883-890.

Singh, K., Agarwal, A., 2020. Impact of weather indicators on the COVID-19 outbreak: A multi-state study in India. medRxiv 1-12. https://doi.org/10.1101/2020.06.14.20130666

Wang, M., Jiang, A., Gong, L., Lu, L., Guo, W., Li, Chuyi, Zheng, J., Li, Chaoyong, Yang, B., Zeng, J., Chen, Y., Zheng, K., Hongyan Li, 2020. Temperature Significantly Change COVID-19 Transmission in 429 cities. medRxiv 1-13. https://doi.org/https://doi.org/10.1101/2020.02.22.20025791

\section{Figures}



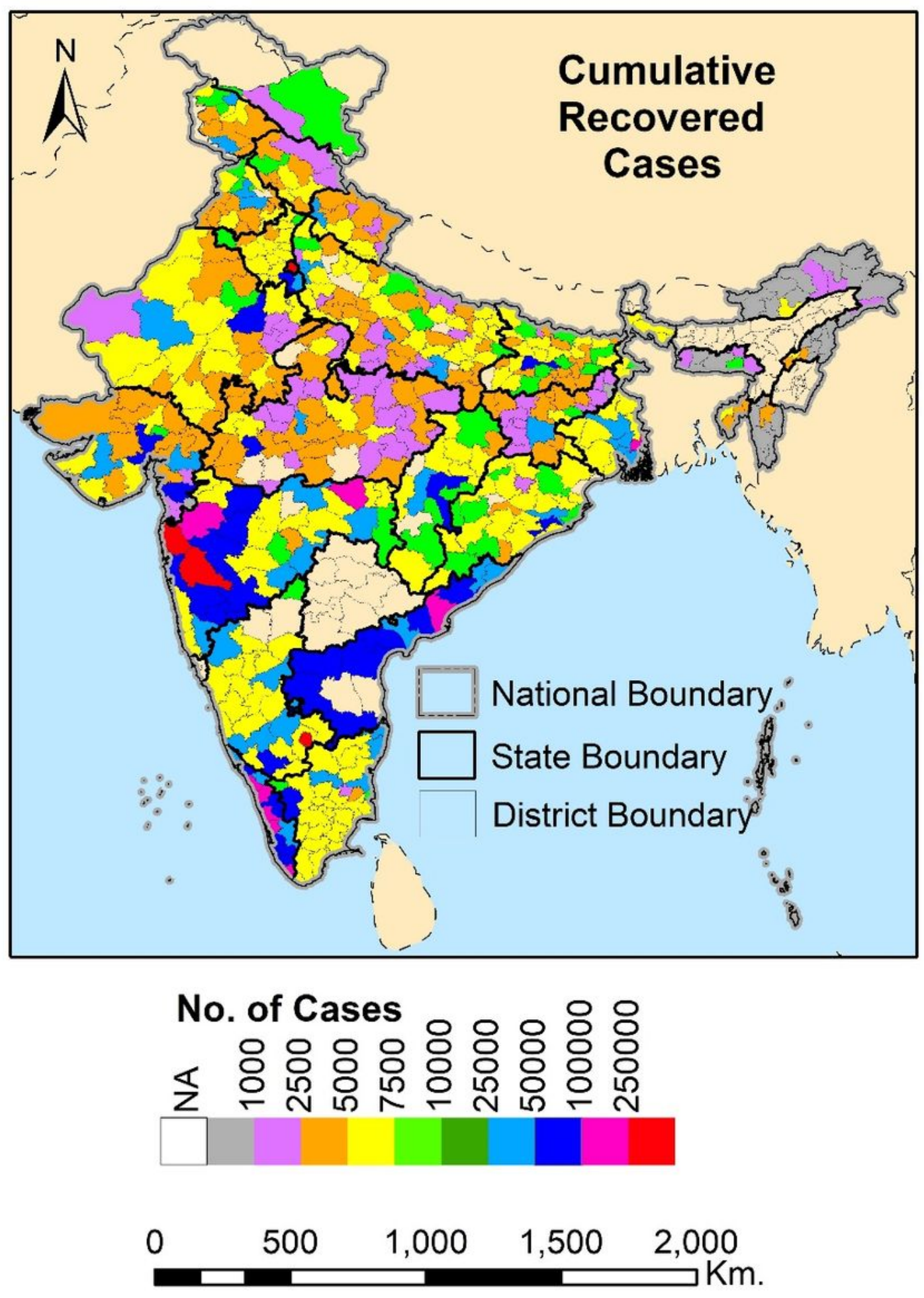

Figure 1

Distribution of recovery cases 


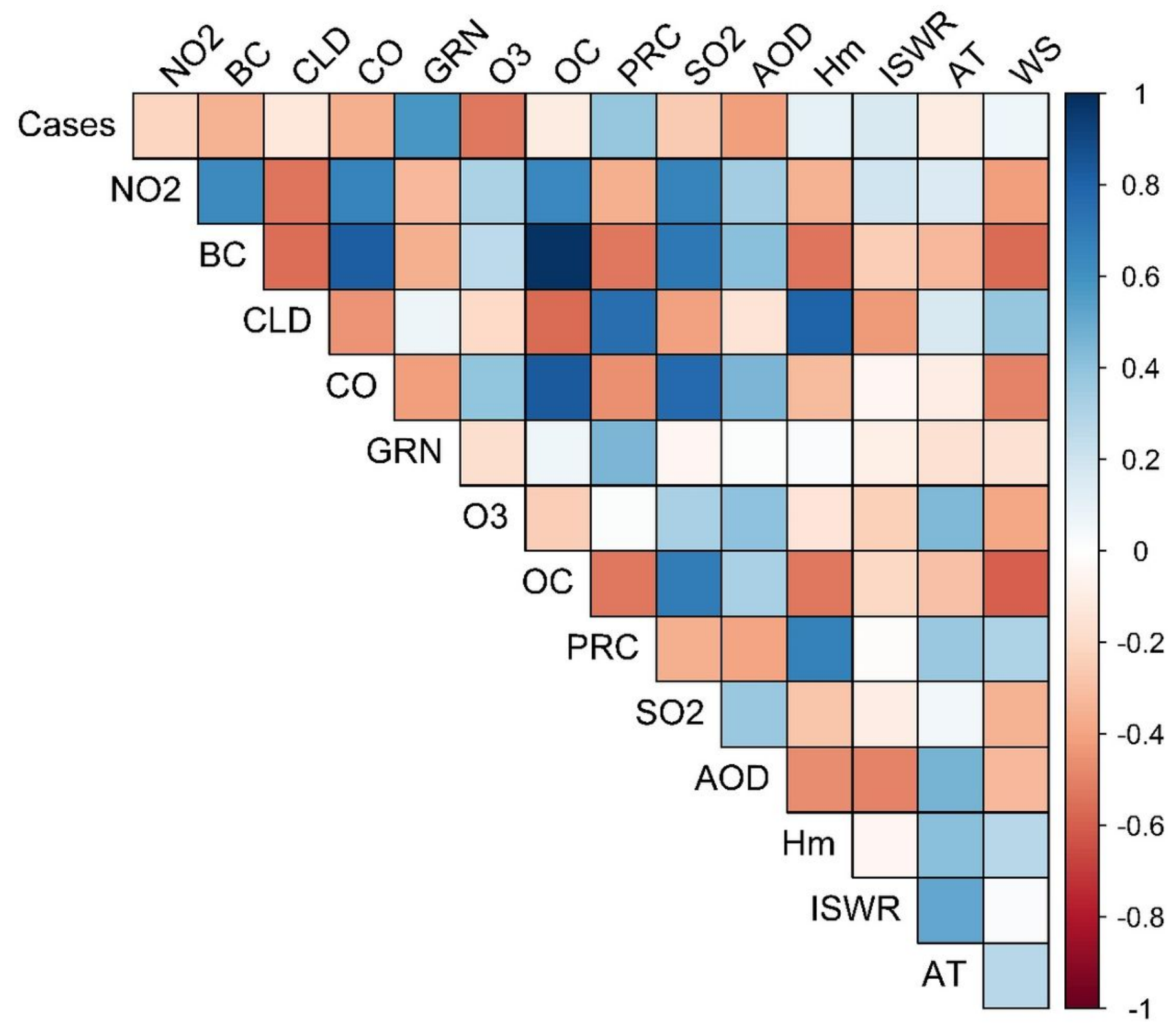

Figure 2

correlogram representing correlations among environmental parameters and recovery cases. 